\title{
Understanding the public sector pay gap
}

\author{
Maria M. Campos ${ }^{1}$, Domenico Depalo ${ }^{2}$, Evangelia Papapetrou ${ }^{3}$, Javier J. Pérez ${ }^{4 *}$ and Roberto Ramos ${ }^{4}$ (D)
}

*Correspondence:
javierperez@bde.es
${ }^{4}$ Bank of Spain, Calle Alcalá 48,
28014 Madrid, Spain
Full list of author information is
available at the end of the article

available at the end of the article

\begin{abstract}
We uncover the short- and long-run structural determinants of the existing cross-country heterogeneity in public-private pay differentials for a broad set of OECD countries. We explore micro data (EU-SILC, 2004-2012) and macro data (1970-2014). Three results stand out. First, when looking at pay gaps based on individual data, more than half of the cross-sectional variation of the sample can be accounted for by the degree of exposure to international competition, as well as by the size of the public sector labor force and its composition (i.e., the intensity in the provision of pure public goods), while labor market institutions play a very limited role. Second, we find that in some countries, pay gaps have narrowed down significantly during the recent financial crisis, this decrease being explained by the widespread process of fiscal consolidation rather than by changes in the previous factors. Third, we show that in the log run, openness to international trade and improvements in the institutional quality of governments are associated with decreases in the public-private wage gap. Our findings can be rationalized by a body of research stressing noncompetitive wage settlements in the public sector.
\end{abstract}

JEL Classification: J31, J45, H50

Keywords: Public sector pay gap, Government monopolistic power, Wage-setting institutions

\section{Introduction}

In this paper, we empirically study the short- and long-run structural determinants of the existing cross-country heterogeneity in public-private pay differentials for a broad set of OECD countries. It has been argued that the existence of positive wage premia may affect labor market outcomes because of distortions on the optimal allocation of the labor force among economic sectors and create overall economy productivity losses. ${ }^{1}$

An extensive literature has dealt with the estimation of public-private wage differentials in a large number of countries. The differentials tend not to be entirely explained by the individual attributes of workers and are found to be heterogeneous across countries both in terms of their size and their sign, even though positive gaps tend to prevail, thus signaling the existence of a so-called public-private pay gap. ${ }^{2}$ Overall, unexplained positive public-private wage differentials tend to be larger for female workers, workers at the lower end of the wage distribution, and younger workers. ${ }^{3}$ The existence of earnings differentials between the public and private sectors in a number of countries has also been highlighted by a strand of papers that uses macro (aggregate) data, ${ }^{4}$ which stress the potential distortions in the labor market such a differential may induce. ${ }^{5}$ 
The literature has provided some theoretical explanations to account for the crosscountry heterogeneity in public-private pay gaps. One body of research argues that the monopolistic power of governments in the provision of public services results in noncompetitive wage settlements. For example, starting from the observation that wage gaps tend to be larger in countries with lower shares of government employment, some authors develop models in which a smaller group of public employees derive monopoly power from a tighter control of the production of public goods/services. ${ }^{6}$ The link between the monopolistic power of governments and noncompetitive wage settlements is amplified by the fact that the objective functions of the government and the private sectors may differ: whereas the latter is largely guided by market forces and profit constraints, the former may pursue political motives. For instance, it has been argued that politicians use public employment for redistributive purposes, directing income towards disadvantaged groups, ${ }^{7}$ or that politicians are likely to link public wage agreements to election cycles. ${ }^{8,9}$ In turn, another set of theories stresses the fact that labor market institutions differ markedly between the public and the private sectors. For example, it has been documented that union density tends to be higher in the public sector. ${ }^{10}$ On related grounds, it is argued that a wage premium arises because of differences in the bargaining power within the private and public sectors. ${ }^{11}$ Other explanations are linked to the degree of public wage-setting centralization of countries. ${ }^{12}$

Surprisingly enough, there is very limited empirical evidence that could help validate the alternative theories to explain the public-private pay gap just described. European Commission (2014) provides simple rank correlations between public wage gaps estimated with 2010 data for 26 European Union (EU) countries and some country characteristics, such as labor market institutions and the size of the government as an employer. They find a positive correlation between the public-private wage gap and employment protection legislation, and conjecture that this might arise because higher compensations are needed to make public employment attractive when private employment is more strongly protected. They also find a negative correlation with the size of public employment in the labor force, as also shown by others. ${ }^{13}$ In turn, within the public administration literature, Llorens (2008) studies the determinants of US state-level public-private wage gaps and finds that, in particular cases, state unemployment, citizen liberalism, and unionization affect the gap positively.

In this paper, we aim to fill in this gap in the literature by providing broad-based empirical evidence on the variables driving the cross-country variation in public-private wage premia. To do so, we use two different and complementary data sets to compute wage gaps. First, we estimate public-private pay gaps for 25 (mostly EU) countries on the basis of data from the "European Union Survey of Living Conditions"(EU-SILC henceforth) for the period 2004 to 2012. Following the extant literature, we define public workers as those employed in the Public Administration, Education, and Health industries, as opposed to market activities, which constitute the private sector. The estimated public pay gaps are at the average of the distribution and control for observable characteristics of workers. Second, in order to expand the sample and analyze medium-term determinants, we use national accounts data for the period 1970-2014, covering 19 developed countries. In this case, by using aggregate data, we define the public pay gap as the ratio of total compensation per employee in the general government sector over that of the private sector. 
Our main findings are the following. First, we show that more than half of the crosssectional variation in micro-data-based public pay gaps over 2004-2012 can be accounted for by the size and composition (specialization in public or individual goods) of the public labor force, as well as exposure to international competition. Second, and on related grounds, we estimate that wage differentials in some countries have narrowed down significantly during the recent financial crisis. Nevertheless, pay gap changes between 2007 and 2012 can be explained by the widespread process of fiscal consolidation rather than by the previous factors. Third, from a long-run perspective (using macro data), we show that openness to international trade and improvements in the quality of governments have been associated with decreases in the public wage gap.

The rest of the paper is organized as follows. Section 2 describes the database, the estimation of the public pay gaps with micro data, and the linkages between different (micro and macro) measures of the gap. Section 3 analyzes the determinants of the cross-country variation of pay gaps. First, of the cross section of gaps estimated with micro data, next by exploiting the variation witnessed in the recent financial crisis, and, finally, adopting a long-run perspective. Finally, Section 5 gives concluding remarks.

\section{Data and variables}

\subsection{The public-private pay gap with micro data}

As regards sources of micro data, we use the "European Union Statistics on Income and Living Conditions" (EU-SILC) survey, given its cross-country comparability, data availability for the pre- and post-crisis periods (2004-2012), and the fact that it covers most of European Union countries. Our sample includes all EU28 countries (with the exception of Bulgaria, Malta, Romania, Finland, and Croatia), as well as Norway and Iceland. The distinction between public and private sector employment is based on NACE (Statistical Classification of Economic Activities), Rev.2. The most recent data refers to the 2013 EUSILC wave, which includes employment and earnings information pertaining to 2012. In this framework, as it is standard in the literature, the "government sector" is an approximation based on either the aggregation of the $\mathrm{O}$ (Public Administration and Defense, Compulsory Social Security), P (Education), and Q (Health and social work) sectors of the NACE classification (broad definition), or only the O sector (restricted definition). With the EU-SILC database, it is not possible to separate public employees from private sector employees in any of the sectors, being this particularly relevant for activities $\mathrm{P}$ and $\mathrm{Q}$, where private providers are more prevalent. ${ }^{14}$ In the case of EU-SILC data, the definition of "wages per employee" is computed based on the individual gross monthly earnings (including only monetary earnings and excluding financial income from investments, assets, savings, stocks, and shares) before netting out taxes and social contributions and the number of hours worked per week in the main job. Note also that the self-employed are excluded from the analysis.

We estimate the part of the wage gap that cannot be accounted for by (observable) individual characteristics. We follow the common approach of running Mincer-type wage regressions taking the logarithm of gross income per hour as the dependent variable. The set of covariates includes binary variables denoting married status, low and high education, managerial position, part-time job, gender, year, and region (2-digit NUTS) fixed effects, as well as a second-degree polynomial in experience (or age and age squared whenever information on experience is not available). ${ }^{15}$ 
The specification also includes a binary variable (public) denoting that the individual works in the public sector. Thus, as per the usual approach, the coefficient associated with the variable (public) represents the earnings differential (evaluated at the mean of the distribution) that remains once the other relevant determinants are controlled for, and if estimated to be positive, it is labeled a public-private pay differential/premium/gap (or pay penalty if negative). ${ }^{16}$

The specification for each country looks as follows:

$$
y_{i}=X_{i} \beta+\delta \text { public }_{i}+\sum_{t=2004}^{2012} \lambda_{t}+\epsilon_{i}
$$

where $\epsilon_{i}$ is an iid idiosyncratic error term and the coefficients $\beta, \delta$, and $\sum_{t=2004}^{2012} \lambda_{t}$ are estimated by ordinary least squares (OLS). Table 1 shows the estimates of the coefficient $\delta$, i.e., the public sector pay gap. In a subsequent section of the paper, we will identify the variables that account for the cross-sectional heterogeneity of $\delta$, its evolution during the recent financial crisis, and its dynamics during the last decades.

Individual characteristics account for a substantial fraction of the observed publicprivate wage gap, but there remains an unaccounted gap. For the pool of euro area countries, the estimated wage gap conditional on characteristics over the 2004-2012 period for the broad NACE proxy to the government sector (OPQ sectors) is $60 \%$ lower than the estimated unconditional wage gap (Table 1, column (2) versus (1)), since the observable characteristics between the two sectors are different, e.g., in the public sector, workers are on average better educated than in the private sector. For the period 2004-2012 as a whole, positive wage gaps are estimated for 21 out of the 23 analyzed EU countries. Conditional wage gaps are larger for countries that suffered fiscal stress over the crisis (Cyprus, Spain, Ireland, Portugal, Greece, and Italy) and Luxembourg and tend to be higher when a more restricted definition of the government sector (NACE O sector) is considered (Table 1, column (5)), i.e., when looking at the sectors in which there exists a quasi-monopoly power of the government as service provider. There has been a reduction in some countries in the estimated (conditional) wage gap as a consequence of the economic crisis and the recent fiscal consolidation episode (Table 1, column (4) versus (3)). For the euro area as a whole (pool), the estimated conditional wage gap for the period 2010-2012 for the broad NACE proxy of government-related activities is $40 \%$ lower than the one estimated for the 2004-2009 period. In general, the wage premium falls more markedly in countries with larger pre-crisis levels.

\subsection{The public-private pay gap with macro data}

Regarding macro (aggregate) data, we focus on the general government sector as defined by the National Accounts, for the period 1970-2014. The longer time span is the first advantage of complementing micro-based pay gaps with gaps computed from macro data. In this latter case, our sample covers 19 developed countries, those for which we were able to gather long time series on the relevant variables: Austria, Belgium, Canada, Germany, Denmark, Spain, Finland, France, Greece, Ireland, Italy, Japan, Luxembourg, Netherlands, Norway, Portugal, Sweden, UK, and USA. The primary source of government wage bill data and all macroeconomic variables used throughout the study (GDP, prices, total economy wages and employment, population) is Eurostat for EU countries and the OECD (Economic Outlook Database) for non-EU countries (see Table 7 of Appendix 1 for the 
Table 1 Estimates of the public pay gap EU-SILC 25 countries

\begin{tabular}{|c|c|c|c|c|c|}
\hline & $\begin{array}{l}\text { Full sample } \\
2004-2012 \\
\text { (1) }\end{array}$ & $\begin{array}{l}\text { Full sample } \\
2004-2012 \\
\text { (2) }\end{array}$ & $\begin{array}{l}\text { Pre-crisis } \\
2004-2009 \\
(3)\end{array}$ & $\begin{array}{l}\text { Crisis } \\
2010-2012 \\
\text { (4) }\end{array}$ & $\begin{array}{l}\text { Full sample } \\
2004-2012 \\
\text { (5) }\end{array}$ \\
\hline \multicolumn{6}{|c|}{ Dep. variable: gross income per hour } \\
\hline Euro area pool & $\begin{array}{l}0.182^{* * *} \\
(0.002)\end{array}$ & $\begin{array}{l}0.074^{* * *} \\
(0.002)\end{array}$ & $\begin{array}{l}0.089^{* * *} \\
(0.003)\end{array}$ & $\begin{array}{l}0.048^{* * *} \\
(0.004)\end{array}$ & $\begin{array}{l}0.100^{* * *} \\
(0.003)\end{array}$ \\
\hline Belgium (BE) & $\begin{array}{l}0.064^{* * *} \\
(0.006)\end{array}$ & $\begin{array}{l}0.005 \\
(0.005)\end{array}$ & $\begin{array}{l}-0.001 \\
(0.007)\end{array}$ & $\begin{array}{l}0.018^{*} \\
(0.010)\end{array}$ & $\begin{array}{l}0.039 * * * \\
(0.007)\end{array}$ \\
\hline Germany (DE) & $\begin{array}{l}0.096^{* * *} \\
(0.006)\end{array}$ & $\begin{array}{l}0.019^{* * *} \\
(0.006)\end{array}$ & $\begin{array}{l}0.025^{* * *} \\
(0.008)\end{array}$ & $\begin{array}{l}0.009 \\
(0.009)\end{array}$ & $\begin{array}{l}0.118^{* * *} \\
(0.005)\end{array}$ \\
\hline Estonia (EE) & $\begin{array}{l}0.037^{* * *} \\
(0.010)\end{array}$ & $\begin{array}{l}0.058^{* * *} \\
(0.009)\end{array}$ & $\begin{array}{l}0.048^{* * *} \\
(0.011)\end{array}$ & $\begin{array}{l}0.080^{* * *} \\
(0.015)\end{array}$ & $\begin{array}{l}0.129^{* * *} \\
(0.014)\end{array}$ \\
\hline Ireland (IE) & $\begin{array}{l}0.347^{* * *} \\
(0.009)\end{array}$ & $\begin{array}{l}0.207^{* * *} \\
(0.009)\end{array}$ & $\begin{array}{l}0.200^{* * * *} \\
(0.011)\end{array}$ & $\begin{array}{l}0.220^{* * *} \\
(0.015)\end{array}$ & $\begin{array}{l}0.193^{* * *} \\
(0.012)\end{array}$ \\
\hline Greece (GR) & $\begin{array}{l}0.382^{* * *} \\
(0.007)\end{array}$ & $\begin{array}{l}0.188^{* * *} \\
(0.006)\end{array}$ & $\begin{array}{l}0.207^{* * *} \\
(0.007)\end{array}$ & $\begin{array}{l}0.150^{* * *} \\
(0.012)\end{array}$ & $\begin{array}{l}0.110^{* * *} \\
(0.007)\end{array}$ \\
\hline Spain (ES) & $\begin{array}{l}0.369^{* * *} \\
(0.004)\end{array}$ & $\begin{array}{l}0.265^{* * *} \\
(0.004)\end{array}$ & $\begin{array}{l}0.266^{* * *} \\
(0.005)\end{array}$ & $\begin{array}{l}0.262^{* * *} \\
(0.007)\end{array}$ & $\begin{array}{l}0.193^{* * *} \\
(0.005)\end{array}$ \\
\hline France (FR) & $\begin{array}{l}0.045^{* * *} \\
(0.006)\end{array}$ & $\begin{array}{l}0.025^{* * *} \\
(0.007)\end{array}$ & $\begin{array}{l}0.047^{* * * *} \\
(0.007)\end{array}$ & $\begin{array}{l}-0.091^{* * *} \\
(0.020)\end{array}$ & $\begin{array}{l}0.042^{* * *} \\
(0.008)\end{array}$ \\
\hline Italy (IT) & $\begin{array}{l}0.285^{* * *} \\
(0.003)\end{array}$ & $\begin{array}{l}0.176^{* * * *} \\
(0.003)\end{array}$ & $\begin{array}{l}0.187^{* * * *} \\
(0.004)\end{array}$ & $\begin{array}{l}0.151^{* * *} \\
(0.005)\end{array}$ & $\begin{array}{l}0.106^{* * *} \\
(0.004)\end{array}$ \\
\hline Cyprus (CY) & $\begin{array}{l}0.508^{* * *} \\
(0.011)\end{array}$ & $\begin{array}{l}0.390^{* * *} \\
(0.009)\end{array}$ & $\begin{array}{l}0.371^{* * *} \\
(0.012)\end{array}$ & $\begin{array}{l}0.417^{* * *} \\
(0.013)\end{array}$ & $\begin{array}{l}0.271^{* * *} \\
(0.010)\end{array}$ \\
\hline Latvia (LV) & $\begin{array}{l}0.211^{* * *} \\
(0.013)\end{array}$ & $\begin{array}{l}0.111^{* * *} \\
(0.013)\end{array}$ & $\begin{array}{l}0.141^{* * *} \\
(0.019)\end{array}$ & $\begin{array}{l}0.073^{* * *} \\
(0.016)\end{array}$ & $\begin{array}{l}0.170^{* * *} \\
0.018)\end{array}$ \\
\hline Lithuania (LT) & $\begin{array}{l}0.242^{* * *} \\
(0.013)\end{array}$ & $\begin{array}{l}0.113^{* * *} \\
(0.015)\end{array}$ & $\begin{array}{l}0.113^{* * *} \\
(0.015)\end{array}$ & $\begin{array}{l}0.211^{* * *} \\
(0.023)\end{array}$ & $\begin{array}{l}0.154^{* * *} \\
(0.023)\end{array}$ \\
\hline Luxembourg (LU) & $\begin{array}{l}0.272^{* * *} \\
(0.012)\end{array}$ & $\begin{array}{l}0.255^{* * *} \\
(0.009)\end{array}$ & $\begin{array}{l}0.239^{* * *} \\
(0.012)\end{array}$ & $\begin{array}{l}0.284^{* * *} \\
(0.014)\end{array}$ & $\begin{array}{l}0.257^{* * *} \\
(0.012)\end{array}$ \\
\hline Netherlands (NL) & $\begin{array}{l}0.137^{* * *} \\
(0.014)\end{array}$ & $\begin{array}{l}0.093^{* * * *} \\
(0.009)\end{array}$ & $\begin{array}{l}0.070^{* * * *} \\
(0.011)\end{array}$ & $\begin{array}{l}0.128^{* * *} \\
(0.014)\end{array}$ & $\begin{array}{l}0.159^{* * *} \\
(0.011)\end{array}$ \\
\hline Austria (AT) & $\begin{array}{l}0.186^{* * *} \\
(0.006)\end{array}$ & $\begin{array}{l}0.090^{* * *} \\
(0.006)\end{array}$ & $\begin{array}{l}0.091^{* * *} \\
(0.006)\end{array}$ & $\begin{array}{l}0.088^{* * *} \\
(0.010)\end{array}$ & $\begin{array}{l}0.054^{* * *} \\
(0.008)\end{array}$ \\
\hline Portugal (PT) & $\begin{array}{l}0.422^{* * *} \\
(0.008)\end{array}$ & $\begin{array}{l}0.195^{* * *} \\
(0.007)\end{array}$ & $\begin{array}{l}0.204^{* * *} \\
(0.008)\end{array}$ & $\begin{array}{l}0.175^{* * *} \\
(0.011)\end{array}$ & $\begin{array}{l}0.207^{* * *} \\
(0.009)\end{array}$ \\
\hline Slovenia (SI) & $\begin{array}{l}0.244^{* * *} \\
(0.007)\end{array}$ & $\begin{array}{l}0.109^{* * *} \\
(0.011)\end{array}$ & $\begin{array}{l}0.090^{* * *} \\
(0.012)\end{array}$ & $\begin{array}{l}0.135^{* * *} \\
(0.019)\end{array}$ & $\begin{array}{l}0.086^{* * *} \\
(0.016)\end{array}$ \\
\hline Slovakia (SK) & $\begin{array}{l}0.064^{* * *} \\
(0.006)\end{array}$ & $\begin{array}{l}0.046^{* * *} \\
(0.006)\end{array}$ & $\begin{array}{l}0.056^{* * *} \\
(0.007)\end{array}$ & $\begin{array}{l}0.028^{* * *} \\
(0.010)\end{array}$ & $\begin{array}{l}0.104^{* * *} \\
(0.007)\end{array}$ \\
\hline Czech Republic (CZ) & $\begin{array}{l}0.102^{* * *} \\
(0.006)\end{array}$ & $\begin{array}{l}0.087^{* * *} \\
(0.006)\end{array}$ & $\begin{array}{l}0.094^{* * *} \\
(0.007)\end{array}$ & $\begin{array}{l}0.073^{* * *} \\
(0.010)\end{array}$ & $\begin{array}{l}0.132^{* * *} \\
(0.008)\end{array}$ \\
\hline Denmark (DK) & $\begin{array}{l}0.035^{* * *} \\
(0.012)\end{array}$ & $\begin{array}{l}-0.058^{* * *} \\
(0.012)\end{array}$ & $\begin{array}{l}-0.064^{* * *} \\
(0.014)\end{array}$ & $\begin{array}{l}-0.041^{*} \\
(0.022)\end{array}$ & $\begin{array}{l}0.027^{*} \\
(0.016)\end{array}$ \\
\hline
\end{tabular}


Table 1 Estimates of the public pay gap EU-SILC 25 countries (Continued)

\begin{tabular}{llllll}
\hline Hungary (HU) & $0.180 * * *$ & $0.042^{* * *}$ & $0.075^{* * *}$ & -0.003 & $0.128^{* * *}$ \\
& $(0.006)$ & $(0.006)$ & $(0.008)$ & $(0.008)$ & $(0.008)$ \\
Poland (PL) & $0.301^{* * *}$ & $0.119^{* * *}$ & $0.117^{* * *}$ & $0.120^{* * *}$ & $0.127^{* * *}$ \\
& $(0.005)$ & $(0.005)$ & $(0.006)$ & $(0.008)$ & $(0.007)$ \\
Sweden (SE) & $-0.040^{* * *}$ & $-0.123^{* * *}$ & $-0.127^{* * *}$ & $-0.118^{* * *}$ & $0.034^{* *}$ \\
& $(0.011)$ & $(0.012)$ & $(0.015)$ & $(0.021)$ & $(0.017)$ \\
United Kingdom (UK) & $0.088^{* * *}$ & $0.015^{* * *}$ & $0.016^{* *}$ & 0.013 & $0.129^{* * *}$ \\
& $(0.006)$ & $(0.005)$ & $(0.007)$ & $(0.009)$ & $(0.007)$ \\
Iceland (IS) & $-0.037^{* * *}$ & $-0.123^{* * *}$ & $-0.126^{* * *}$ & $-0.111^{* * *}$ & $0.022^{*}$ \\
& $(0.006)$ & $(0.010)$ & $(0.012)$ & $(0.020)$ & $(0.013)$ \\
Norway (NO) & $-0.067^{* * *}$ & $-0.135^{* * *}$ & $-0.134^{* * *}$ & $-0.132^{* * *}$ & 0.010 \\
& $(0.013)$ & $(0.014)$ & $(0.021)$ & $(0.020)$ & $(0.019)$ \\
Controls & No & Yes & Yes & Yes & Yes \\
Public sector defined as & Broad & Broad & Broad & Broad & Restricted \\
\hline Notes: This trad show & & &
\end{tabular}

Notes: This table shows the estimates of the public sector pay gap conditional on observable characteristics (Eq. 1). The public sector is defined as industries (NACE Rev. 2) O (Public Administration), P (Education), and Q (Health and social work), except column (5), where the public sector only comprises the industry $O$. The dependent variable is gross income per hour, computed as the ratio of individual gross monthly earnings (including only monetary earnings and excluding financial income from investments, assets, savings, stocks, and shares) before netting out taxes and social contributions and the number of hours worked per week in the main job. Controls include the following: binary variables denoting public sector (which coefficient is shown) married status, low and high education, managerial position, part-time job, gender, year, and region fixed effects, as well as a second-degree polynomial in experience (or age and age squared whenever information on experience is not available). The specification of column (1) does not include observable characteristics (unconditional public sector pay gap). Robust standard errors are in parenthesis, clustered at the individual level

Significance levels: ${ }^{* 10 \% ; * *} \%$; *** $1 \%$

definition and sources of all the variables used in the paper). General government employment data, in turn, are taken from the OECD database. The measure of aggregate (macro) wages chosen for our analysis is compensation per employee. The main reason why we focus on total compensation rather than on wages is data limitations in terms of sample size and coverage of countries in our sample. We compute compensation per employee using compensation of employees and employment data. Compensation of private sector employees is defined as total economy compensation of employees minus compensation of government employees. Compensation per private employee is defined as private compensation of employees divided by total employees minus government employment minus self-employment. In Fig. 1a, b, we show the evolution over time of public-private pay differentials for a selection of countries. The evolution of the wage gaps is to a high extent country-specific, although there exists a pattern of decreasing pay gaps in the 1970s, stabilization, and a subsequent increase since the 1990s, at least for some countries. Regarding the level, countries in northern Europe have lower and negative pay differentials when compared with other EU countries, the USA, and Japan.

The use of macro data allow us to use a delimitation of the government sector, the general government, that is more accurate that the approximation based on nonmarket activities (NACE sectors $\mathrm{O}, \mathrm{P}$, and $\mathrm{Q}$ ) used in the previous section. ${ }^{17}$ The main disadvantage is that the wage gap thus computed does not control for characteristics of the labor force; therefore, it tends to be larger. We will address this bias on a subsequent section by performing our regressions in first differences, hence removing this bias in levels. Our implicit assumption is that the bias remains relatively constant over time. 

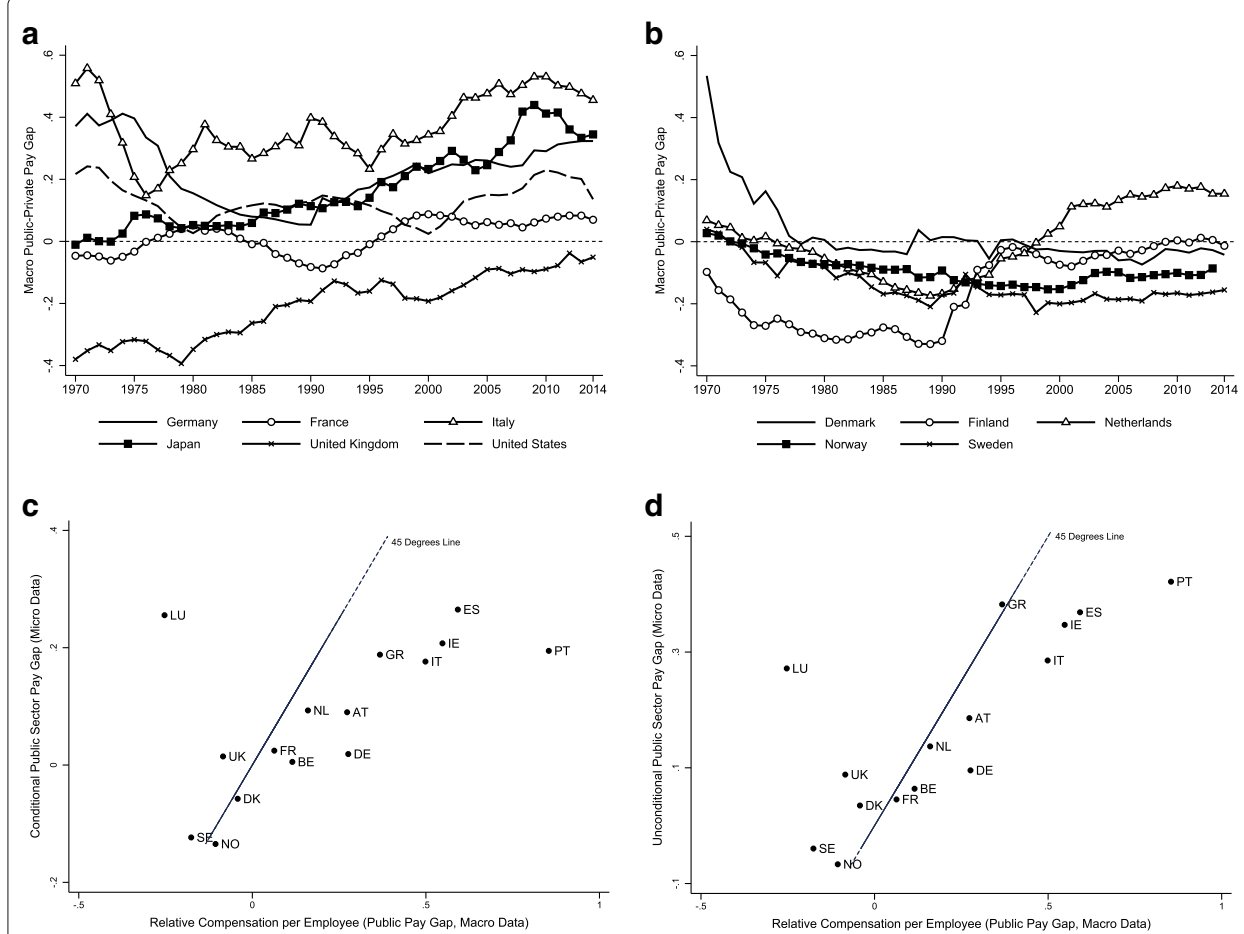

Fig. 1 Public-private pay differentials computed from macro data and comparison with micro-based pay gaps. Notes: Panels $\mathbf{a}$ and $\mathbf{b}$ show the evolution of public-private pay differentials (computed from macro data) for a selection of countries. Panel c compares the public sector pay gap conditional on observed worker characteristics (EU-SILC, see Eq. 1) with the wage gap computed from aggregate macro data (National Accounts). Panel $\mathbf{d}$ compares the latter with the public sector pay gap computed from micro data (EU-SILC) unconditional on observed characteristics. With the exception of Luxembourg, the cross-country patterns of micro vs. macro pay gaps are similar

In Fig. 1c, d, we compare the wage gaps computed from macro data with those computed from micro data, both conditional and unconditional on characteristics (columns (2) and (1) of Table 1, respectively), for the group of countries present in both samples over the sample period in which they overlap (2004-2012). As expected, the wage gaps computed from macro data are generally larger but are much closer to the unconditional wage gaps computed from micro data. More importantly, the cross-country patterns observed in the micro data are preserved in the macro aggregates; hence, the analysis with aggregate data is meaningful. ${ }^{18}$

\subsection{Hypotheses to be tested}

We characterize the variables that explain the cross-country variation in the publicprivate wage gap. Our choice of covariates relies on a body of research that has rationalized the existence of public-private wage differentials. Hence, we view our paper as an empirical test of these theories. According to the literature, conditional on characteristics, public and private sector workers can be paid differently for two broad reasons: (i) the government is the only provider of certain goods and services, which may generate noncompetitive wage settlements. Also, the private and the public sectors may have different objective functions: whereas the former is a profit maximizer, the latter may pursue 
other objectives such as vote maximization and redistribution, which also generate noncompetitive wage policies. (ii) Wage-setting institutions may differ between the private and the public sector (union density, collective bargaining, centralization, etc.).

We proxy for the monopolistic power of governments with four variables. The first is the ratio of public employment over total employment, which accounts for the size of the government sector as an employer. This variable is expected to correlate negatively with the public wage gap: a smaller public labor force is more likely to form an insider group of workers that enjoy market power in the supply of labor to the public sector and hence can settle more favorable wage policies. The second is the ratio of Public Administration employees over total public employees. This accounts for the composition of the public labor force, whether it is tilted towards the provision of pure public goods (those in the Public Administration, where the public sector faces limited competition from the private sector) or to individual goods (like Health and Education, where competition from the private sector is higher). Hence, it is expected to correlate positively with the public wage premium. Third is government effectiveness (from the Worldwide Governance Indicators), which proxy for the institutional quality of the public sector, which are expected to have a negative correlation with the wage gap. Higher wage gaps, being possibly the result of distortions in the economy, are less likely to exist if the quality of institutions is high. And fourth is exposure to international competition. This is expected to have a negative correlation with the wage gap, as foreign competition can help increase the efficiency and discipline the process of setting wages in the economy. ${ }^{19}$ We measure exposure to international competition with the share of tradable sectors (agriculture and manufacturing) in total value added. We also use an index of openness, the ratio of imports and exports over GDP.

Our test on the second set of theories relies also on four variables. First is the measure of how much legislation protect workers (OECD), namely the degree of employment protection in the economy, which is expected to correlate positively with the wage gap. In view of the theories highlighting wage-setting institutions, we expect that countries with a higher protection of employment will exhibit higher public pay gaps, since the better the conditions to work in the private sector, the higher the required wages in the public sector in order to attract workers. Second, countries with a higher trade union density (both in the public and in the private sectors) will exhibit generally lower wage gaps, since trade unions are more likely to reduce the dispersion of wages by collective bargaining. Regarding the relationship between union density and the wage gap, probably the crucial determinant is the difference in union density between the public and the private sector. We test if this variable has predictive power in explaining the wage gap, but our analysis is limited by a too small number of observations with the available data. Third, we include an indicator of whether wages in the government sector are settled by collective bargaining as opposed to unilateral decisions. Collective bargaining is more likely to reduce the wage gap, if the bargaining process involves independent bodies that take into account the labor conditions in the economy. Finally, we include an indicator of centralization in the update of government wages. If wage updates in the government sector are centralized, the wage gap is expected to be higher, as public wages are more likely to deviate from the conditions of local labor markets.

Our choice of variables referring to each class of models stems from the empirical implications they entail. We stress size, composition, quality, and efficiency of the public sector 
as more related to the monopolistic power of governments and labor market institutions as more related to public wage settlements. It must be stressed though that this taxonomy is sometimes not straightforward, and some variables could be justified in the context of both types of models. We follow this approach to ease exposition and because it provides a suitable guidance to specify the regressions.

\section{The determinants of the public-private wage gap}

\subsection{Cross-sectional determinants of the micro estimates}

Given that our OLS cross-section regressions are performed on a small number of observations (25 countries for which we have estimates of the wage gap), we first explore the relationship of the wage gap with the variables linked to the monopolistic power of the government sector and, separately, to those proxying for wage-setting institutions. In a third specification, we add together those variables that were significant in the first stage and also add other proxies for economic conditions, namely per capita GDP, deficit, debt, and GDP growth, in order to check the robustness of the results.

\subsubsection{The government monopolistic power and the wage gap}

We start by drawing the scatterplots of the variables capturing the monopolistic power of governments with the wage gap (see Fig. 2), where the corresponding bivariate regressions are showed in Table 8 in the Appendix 2. A simple inspection of the raw data reveals that some of the patterns predicted by the theory hold (unconditionally) in our sample of countries. We find that in countries with smaller public labor forces, public workers relatively concentrated in Public Administration, and with less effective governments, pay gaps are significantly larger. Also, less exposure to international competition is associated with higher gaps, although this relationship is not statistically significant.

Moreover, some consistent patterns across country groups are apparent. For example, the Nordic countries (Denmark, Iceland, Norway, and Sweden) are characterized by large public labor forces in which the share of Health and Education is relatively higher (see Fig. 2a, b), two features that, according to the theories developed by the literature, support the finding that these countries experience the lowest pay gaps. Furthermore, the Nordic countries are the best performers in government effectiveness, a feature that also goes in favor of low gaps. On the opposite side, the Mediterranean nations (Cyprus, Spain, Greece, Italy, and Portugal) are characterized by large public labor forces specialized in Public Administration and relatively low levels of government effectiveness; thus, they deliver higher pay gaps. Some Central and Eastern European countries (Estonia, Latvia, Lithuania, Slovenia, Slovakia, Czech Republic, Hungary, and Poland) render roughly average wage gaps, which is consistent with shares of Public Administration workers also around the average. Yet, they are characterized by small public labor forces and low levels of government effectiveness. The remaining Central European countries (Austria, Belgium, Netherlands, Germany, France, and the UK) have also average pay gaps, which goes in line with government effectiveness levels slightly above the mean. Also, Germany, France, and the UK employ neither small nor big public labor forces, while the share of public employees is large in Belgium and the Netherlands and small in Austria. Two countries do not seem to belong to a specified category. Luxembourg and Ireland undergo the third and fourth largest pay gaps, respectively, in our sample, yet they enjoy high-quality governments and a fair amount of public employees. Despite this, they behave according 


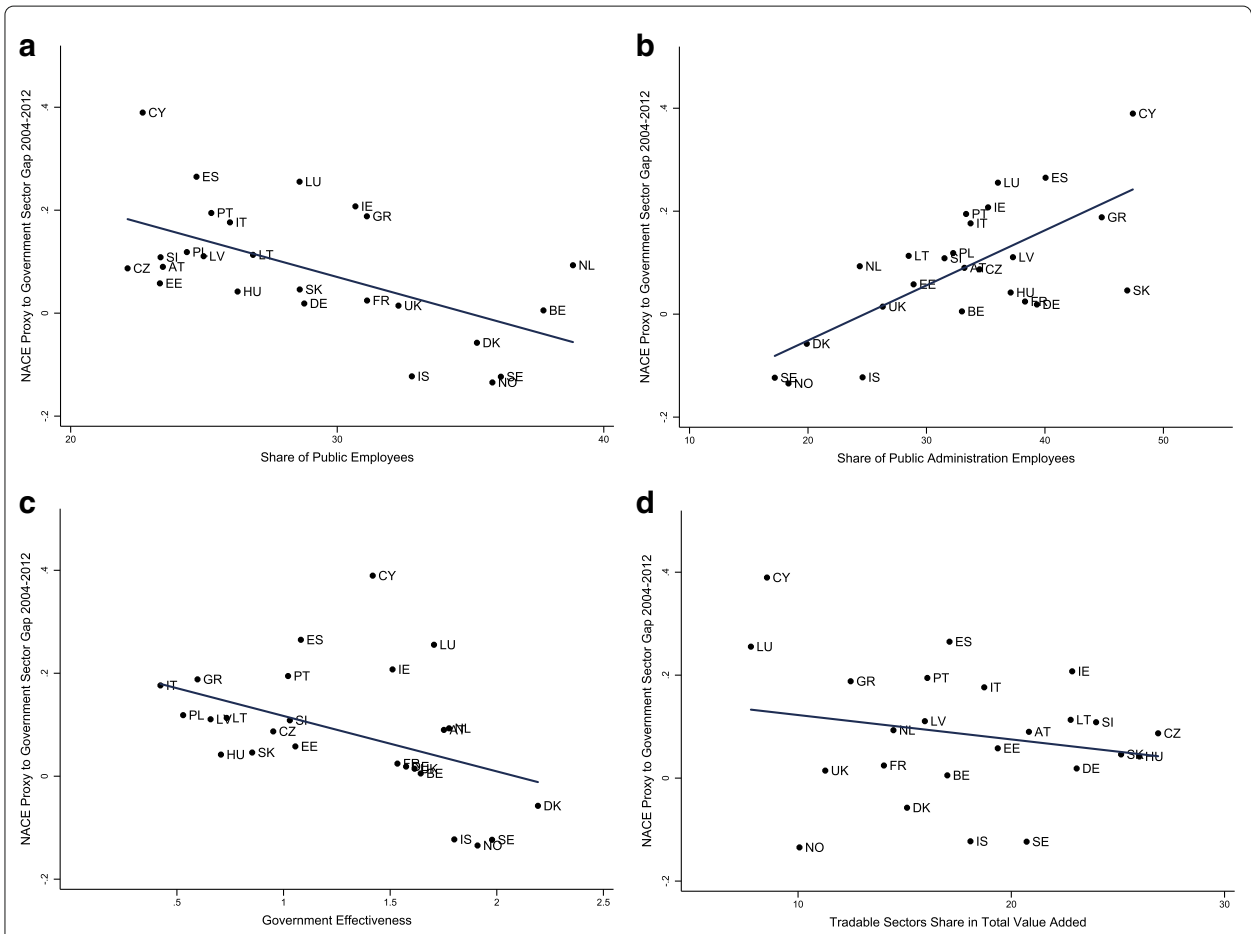

Fig. 2 a-d The monopolistic power of governments and the wage gap: bivariate relationships. Notes: This figure shows the scatterplots of the variables capturing the monopolistic power of governments with the public sector conditional pay gap. The pay gap is estimated from micro data for the period 2004-2012; see Table 1. Panels a to $\mathbf{d}$ show the correlation between the wage gap and the share of public employees, the ratio of Public Administration Employees (over public employees), the government effectiveness and the share of tradable sectors in total value added, respectively

to the theory in the sense that they allocate a relatively high amount of workers to Public Administration, rather than to Health and Education. Overall, these results suggest that the characteristics linked to the monopolistic power of governments, which are somewhat comparable across countries within each group, help understand the cross-country variation of the public sector pay gap. Furthermore, to the extent that some theoretical works have rationalized the observed relationships, this evidence provides support to them.

The bivariate relationships just discussed may overlook relevant interactions between the explanatory variables that can affect the correlations uncovered above. For this reason, it is worth exploring the relationship of these variables with the wage gap in a multivariate regression framework. In Table 2, we show the results of regressing the wage gap on all the variables capturing the degree of the monopolistic power of governments. ${ }^{20}$ The results tend to confirm the previous findings, with some qualifications. Column (1) shows that, conditional on the rest of the covariates, countries with a lower percentage of public employees, a composition of the public workforce tilted towards goods that are provided exclusively by the public sector, and that are less opened to international competition, have significantly higher wage gaps. Quantitatively, a one standard deviation decrease in the percentage of public employees (5.1 percentage points, being the mean $29.0 \%$ ) is associated with an increase in the public pay gap of 5.2 percentage points (or 0.41 standard deviations, being the mean 8.5\%); a one standard deviation increase in the share of public workers in the Public Administration with respect to overall public workers (8.3 percentage points, being the mean $32.9 \%$ ) is associated with an increase of the public pay gap 
Table 2 Determinants of the public sector pay gap: government monopolistic power

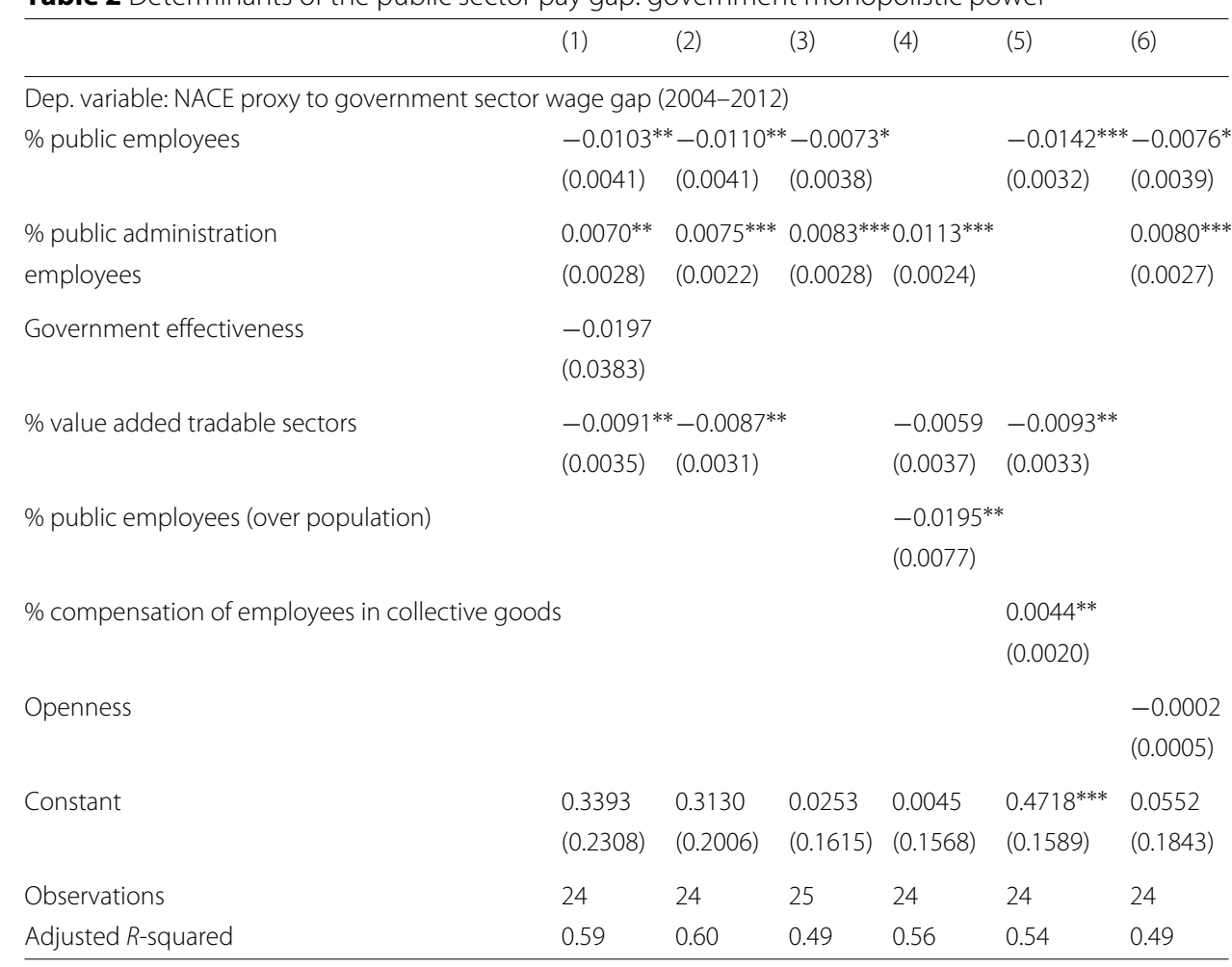

Notes: This table shows the regression of the public sector pay gap on country characteristics linked to the government monopolistic power in the provision of public services. The regression in column (6) excludes Luxembourg, as its openness is an outlier with respect to the sample (larger than the mean plus 5 standard deviations). Robust standard errors are in parenthesis Significance levels: ${ }^{*} 10 \%$; ${ }^{* *} 5 \%$; $* * * 1 \%$

of 5.8 percentage points; and a one standard deviation increase in the share of tradable sectors in total value added (5.4 percentage points, being the mean $17.7 \%$ ) is associated with a decrease in the wage gap of 5.0 percentage points. It is worth noting that this variable did not render a significant relationship with the pay gap in the bivariate framework (although it had the same sign), while the opposite happens for government effectiveness. This is so because there is a negative correlation, at least in our sample, between the quality of governments and the composition of public employment. That is, countries with more efficient governments employ a lower share of workers in Public Administration (relative to Health and Education), and they have on average lower gaps. Regarding exposure to international competition, the multivariate framework underlines the importance of accounting for the effectiveness of government to empirically verify the correlation between international competition and the wage gap, since, conditional on the latter, more exposure to international competition leads to significantly lower gaps. In column (2), we remove the government effectiveness from the regression and find that the other three variables remain statistically significant. The $R$-squared from this specification shows that these three variables explain $60 \%$ of the variation of the wage gaps in our sample.

Given the small number of observations of these regressions, it is important to check that no outliers drive these results. In Fig. 3a-c, we plot the correlation between each covariate of the specification in column (2) with the dependent variable once the effect of the other covariates is removed, i.e., the partial correlations. ${ }^{21}$ We can see that these correlations are genuine and are not driven by extreme observations. 

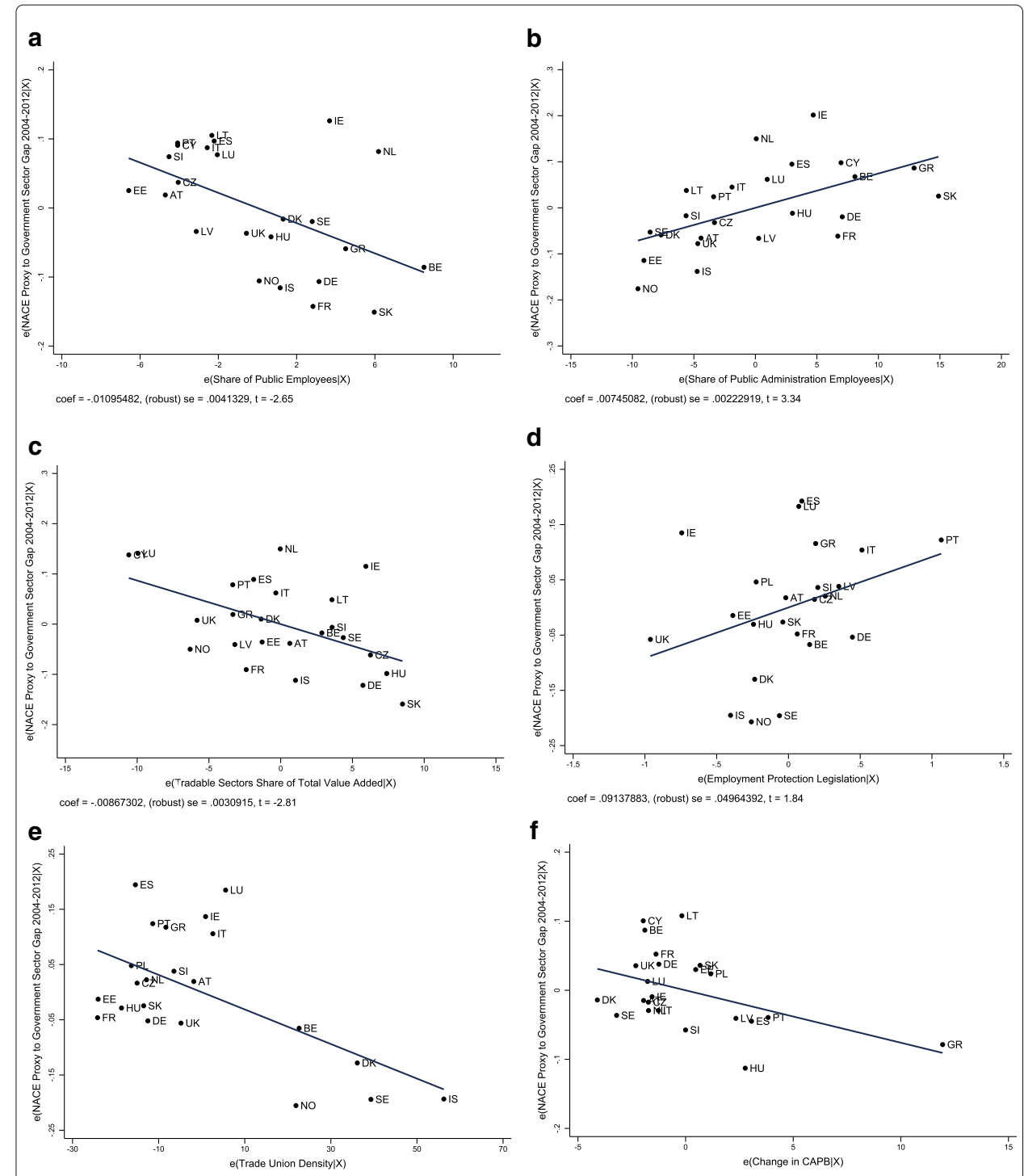

coef $=.00312883$, (robust) se $=.00069517, \mathrm{t}=-4.5$

coef $=-.00759236$, (robust) $\mathrm{se}=.00210682, \mathrm{t}=-3$.

Fig. 3 The public pay gap and potential determinants. Notes: This figure shows the partial correlations between the public sector pay gap and country characteristics. Panels a to c show partial correlations with characteristics linked to the government monopolistic power in the provision of public services; see column (2) of Table 2. Specifically, panels $\mathbf{a}, \mathbf{b}$, and $\mathbf{c}$ show the partial correlation of the size of the public sector (share of public sector employees), the composition of the public sector (specialization in public goods), and the exposure to international trade (specialization in tradable goods), respectively. Panels $\mathbf{d}$ and $\mathbf{e}$ show the correlation (in deviations with respect to the mean) between labor market institutions and the public sector pay gap. Panel $\mathbf{d}$ shows the correlation of an index of employment protection legislation (column (2) of Table 3) and panel $\mathbf{e}$ of an index of trade union density (column (3)). Finally, panel $\mathbf{f}$ shows the correlation (in deviations with respect to the mean) between improvements in the CAPB during the crisis and changes in the public sector pay gap; see column (1) of Table 4. Improvements in the CAPB are computed as the CAPB in 2012 minus the minimum in the period 2007-2011. Changes in the public sector pay gap correspond to the same period

The following columns of Table 2 check the robustness of these findings. Column (3) removes the share of tradable sectors in total value added. The size and composition of the public labor force remain significant explanatory variables of the public pay gap, being able to explain almost half of its variance. Columns (4) to (6) substitute each covariate by an alternative measure, capturing the same economic concept. Column (4) computes the 
size of the public labor force as the percentage of public employees over population, yielding an even lower point estimate. Column (5) substitutes the share of public employees in the Public Administration by the percentage of total compensation of employees aimed at collective goods, whose provision is carried out exclusively by the government sector, as opposed to individual goods, such as health and education (the source of these data is COFOG). This variable is positively correlated with the public pay gap, reinforcing the message that a higher monopolistic power of the government sector is associated with a higher wage gap. Finally, column (6) substitutes the share of tradable sectors in total value added by log openness. In this case, this variable enters nonsignificantly in the regression, although with the expected sign. Overall, these robustness checks are highly supportive of the main findings: the positive association between the public sector pay gap and the monopolistic power that the public sector enjoys in the production of certain goods and services.

Given that both the size and composition of public sector employees are important in explaining the wage gap, it is worth noting that the sign of the latter makes more sense when the private sector is more involved in Health and Education, which renders the former variable, as constructed from the broad definition of the government sector, less accurate. In order to address this concern, we have replaced the percentage of public employees constructed from the broad definition with the percentage of public employees constructed from the restricted definition (i.e., the ratio of Public Administration employees over total employment). We found that the results were very similar. A larger amount of public employees is associated to a significantly lower wage gap, while, conditional on size, the more specialization in public goods, the larger the wage gap. Therefore, the results do not seem to be driven by the specific definition of public sector workers.

While it is very difficult to empirically disentangle the specific mechanisms leading to the observed cross-country correlations, we have delved deeper into the relationship between openness and the wage gap. Specifically, it may be the case that well-run countries have public sectors with low pay gaps and very competitive private sectors, which in turn would lead to more openness to international competition. This would suggest that a third factor, the private sector competitiveness, would explain the correlation between openness and the wage gap. While this concern was partly addressed by adding to the regression the government effectiveness, which controls for the business environment of each country, we have also added a measure of private sector competitiveness in order to check whether conditional on it there is still an association between exposure to international competition and the wage gap. Specifically, we added the OECD product market regulation index, which captures the degree of pro-competition regulation in product markets. ${ }^{22}$ Interestingly, we find that conditional on this variable, we still find that exposure to international competition is significantly associated to the wage gap. Indeed, the coefficient of the share of tradable sectors in total value added remains basically unchanged, and the product market regulation index enters nonsignificantly. This result suggests that international competition may discipline the public and private wages in the economy at least beyond the implementation of policies to promote competition.

\subsubsection{Wage-setting institutions and the wage gap}

In Table 3, we test the theories that link the wage gap with the wage-setting institutions that prevail in the public vs. the private sector. In the joint regression of the wage 
Table 3 Determinants of the public sector pay gap: different wage-setting institutions

\begin{tabular}{|c|c|c|c|c|c|c|}
\hline & $(1)$ & (2) & (3) & (4) & (5) & (6) \\
\hline \multicolumn{7}{|c|}{ Dep. variable: NACE proxy to government sector wage gap (2004-2012) } \\
\hline Employment protection & 0.0415 & $0.0914^{*}$ & & & & \\
\hline Legislation & $(0.0420)$ & $(0.0496)$ & & & & \\
\hline \multirow[t]{2}{*}{ Trade union density } & -0.0017 & & $-0.0031^{* * *}$ & & & \\
\hline & $(0.0015)$ & & $(0.0007)$ & & & \\
\hline \multirow[t]{2}{*}{ Bargaining } & -0.0172 & & & & -0.0414 & \\
\hline & $(0.0506)$ & & & & $(0.0484)$ & \\
\hline \multirow[t]{2}{*}{ Centralization } & 0.0620 & & & & & $0.1086^{* *}$ \\
\hline & $(0.0530)$ & & & & & $(0.0477)$ \\
\hline Public-private & & & & 0.0008 & & \\
\hline Trade union density & & & & $(0.0031)$ & & \\
\hline \multirow[t]{2}{*}{ Constant } & 0.0136 & -0.1688 & $0.1703^{* * *}$ & 0.0435 & $0.1252^{* * *}$ & $0.0677^{* *}$ \\
\hline & $(0.1098)$ & $(0.1426)$ & $(0.0326)$ & (0.0973) & $(0.0239)$ & $(0.0242)$ \\
\hline Observations & 20 & 23 & 22 & 11 & 23 & 23 \\
\hline Adjusted $R$-squared & 0.14 & 0.07 & 0.32 & -0.10 & -0.01 & 0.18 \\
\hline
\end{tabular}

gap against employment protection, trade union density, collective bargaining, and centralization of wage updates, none of the covariates is statistically significant, although employment protection, trade union density, and centralization bear the signs predicted by the theory; see column (1).

In the following columns, we consider the bivariate relationships of each of these variables with the public pay gap. In column (2), we find that a higher protection of private employment is associated with a significantly higher pay gap. Quantitatively, it means that a one standard deviation increase in employment protection is associated with a 3.9 percentage point increase in the public wage gap (0.34 standard deviations). The simple correlation (in deviations with respect to the mean) is displayed in Fig. 3d. We can see that the country groups identified in the previous section shed light on interpreting this result. The Nordic countries display below-average levels of employment protection and low pay gaps, while Southern European countries render exactly the opposite. However, it is worth noting that the Nordic nations exhibit lower gaps than predicted by employment protection, suggesting that other forces drive the gaps down, which is consistent with the pattern of trade union density and the wage gap that we describe below. At the mean of both the wage gap and employment protection lie Central and Eastern European countries. Finally, the case of the UK stands out, since the very low employment protection help rationalize a below-average public sector pay gap.

The next column shows the association of the trade union density with the pay gap. We find that a one standard deviation increase in trade union density is associated with a 6.8 percentage point decrease in the wage gap. The correlation displayed in Fig. 3e makes apparent that this relationship is driven by the Nordic countries. Actually, removing them from the regression yields a nonsignificant relationship between both variables. Moreover, the variable trade union density corresponds to the whole economy. If we consider instead the difference in trade union density between the public and the private sector, 
we do not find a significant relationship with the public pay gap; see column (4). Nevertheless, this result must be taken with caution as the number of observations of this regression is very low. We also consider the relationship between the wage gap and the coverage of collective bargaining agreements, which may capture better the pay homogenization induced by trade unions. This relationship is negative, as expected by theory, but not statistically significant (the $p$ value is 0.17 , not shown).

In column (5), we show that there is no significant bivariate relationship between the wage gap and wages being set by collective bargaining. On the contrary, countries where wage updates are carried out in a centralized manner have on average a wage gap 10.8 percentage points higher than countries where wage updates are decided in a decentralized manner; see column (6). In this regard, it is worth noting that five out of the six countries exhibiting the largest gaps (Cyprus, Luxembourg, Ireland Portugal, and Greece) are characterized by centralized public wage updates, the exception being Spain. Moreover, there are only two countries out of nine (Hungary and France) where wage updates are centralized and the pay gap is below average.

Overall, the results discussed in this section provide some evidence on the link between wage-setting institutions across countries and the public pay gap. However, it must be noted that they explain less of the cross-country variation of the wage gap than theories stressing the monopolistic environment in which governments operate, and the correlations lose their statistical significance once they are computed in a multivariate regression framework.

\subsubsection{Further results in the cross section}

The findings discussed in the previous two sections are further confirmed when we implement a horse race between both theories (not shown). ${ }^{23}$ Specifically, we add together the proxies for the monopolistic power of governments and the wage-setting institutions (the latter added one at a time). When we regress the public wage gap against the percentage of public employees, the share of public employees in Public Administration, the share of tradable sectors in total value added, and the employment protection legislation, it turns out that only those variables reflecting the monopolistic power of the public sector are significant in explaining the wage gap, having similar coefficients as those found in Table 2. This result is confirmed when we include the variable trade union density, whose coefficient is not statistically significant. Moreover, if we add the indicator of centralized wage updates, it also enters nonsignificantly.

We also checked that these results are robust to excluding the years of the financial crisis, which may introduce some noise in the relationship between the wage gap and its fundamentals. Actually, the estimates are more precisely estimated when using the sample 2004-2007, and none of the economic conditions have explanatory power. $^{24}$

In addition, we also check the robustness of the results to adopting a narrower definition of the public sector. We restrict it to Public Administration (industry O), i.e., we consider Education and Health (industries $\mathrm{P}$ and $\mathrm{Q}$ ) to belong to the private sector. We find that the public sector wage gap under such a definition is also significantly related to the size and composition of public sector employees, as well as exposure to international trade. Labor market institutions do not have predictive power in explaining the wage gap, once the other variables are controlled for. ${ }^{25}$ 
We also analyzed the relationship between the overall pay gap and that of female workers and workers at the lower end of the income distribution. If the public sector follows more egalitarian practices in the setting of wages, (at least part of) the overall pay gap may be the result of discrimination (for example, to women) in the private sector. We found that indeed in almost all countries, the conditional pay gap is larger for female workers and workers at the first quartile of the income distribution; see Appendix 2. ${ }^{26}$ However, the cross-country differences in the pay gap of women and low-income workers are virtually the same as those of the overall population (the correlations are .99 and .98 , respectively). Hence, the structural determinants uncovered in this section also account for a large fraction of the cross-country variability in pay gaps of these groups. To sum up, then, we find support that the government monopolistic power explains a large part of the cross-country variation in the public pay gap, at least in our sample of 25 (mostly) EU countries. ${ }^{27}$

\subsection{Exploiting changes during the financial crisis}

During the last few years, a large sample of EU countries have undergone fiscal consolidation processes of different degrees aimed at controlling increasing fiscal deficits stemming from the financial crisis. In this regard, measures focused on restraining the government wage bill played a significant role, with actions on this front being adopted by several countries. We showed in Table 1 that wage gaps in some countries were reduced during the crisis/consolidation period, while in others they remained constant or even increased. Thus, in this section, we study whether the change observed in the gap during this period can be linked to changes in the determinants of the previous section or to the effect of fiscal consolidation measures. Before we proceed, we raise a flag in interpreting the results of this section, given our small sample size, the turbulent times associated with the financial crisis, and the different set of austerity measures undertaken in each country, which may introduce additional noise in the estimations. Moreover, it must be stressed that the pay gap reflects wage developments in both the public and the private sector. Fiscal retrenchment may squeeze public sector wages, while, in parallel, labor market deregulation can reduce wages in the private sector. Hence, differences in labor market developments may result in heterogeneous cross-country outcomes in wage growth and eventually may bring about wage gap increases or decreases.

We define the fiscal effort as the difference in the cyclically adjusted primary balance (CAPB) between 2012 and the minimum of the period 2007-2011. This definition takes into account that some countries carried out front-loaded fiscal consolidations, while others delayed this process. Of the $23 \mathrm{EU}$ countries in our sample, during the period 2007-2012, 18 countries posted the lowest CAPB in 2008-2010, 1 in 2007, 3 in 2011, and only 1 exhibited the worst CAPB in 2012, which was nevertheless contained (Denmark, with a CAPB of 1.7 percent of GDP). Armed with this definition, we study whether countries that made larger fiscal efforts brought the public pay gap down more.

Column (1) of Table 4 shows that indeed improvements in the CAPB have been associated with significant decreases in the public sector pay gap in our sample. The point estimate suggests that a country improving its CAPB in 3.3 percentage points of GDP (the average of our sample) was able to reduce the public pay gap 2.5 percentage points. Note that the average reduction of the pay gap is 1.5 percentage points; hence, this decrease is very large. Figure $3 \mathrm{f}$ shows the correlation (in deviations with respect 
Table 4 The public pay gap during the crisis: determinants of change between 2007 and 2012

\begin{tabular}{|c|c|c|c|c|c|c|}
\hline & $(1)$ & (2) & (3) & (4) & (5) & (6) \\
\hline \multicolumn{7}{|c|}{ Dep. variable: change in NACE proxy to government sector wage gap (2012-year of worst CAPB) } \\
\hline$\Delta_{12-\min } \mathrm{CAPB}_{C}$ & $\begin{array}{l}-0.0076^{* * *} \\
(0.0021)\end{array}$ & $\begin{array}{l}-0.0066^{* * *} \\
(0.0020)\end{array}$ & $\begin{array}{l}-0.0076^{* * *} \\
(0.0022)\end{array}$ & $\begin{array}{l}-0.0081^{* * *} \\
(0.0024)\end{array}$ & $\begin{array}{l}-0.0106^{* * *} \\
(0.0030)\end{array}$ & $\begin{array}{l}-0.0061^{* * *} \\
(0.0016)\end{array}$ \\
\hline$\Delta_{12-\min } \%$ public employees ${ }_{c}$ & & $\begin{array}{l}-0.0061 \\
(0.0073)\end{array}$ & & & & \\
\hline $\begin{array}{l}\Delta_{12-\min } \% \text { public administration } \\
\text { employees }_{C}\end{array}$ & & & $\begin{array}{l}0.0010 \\
(0.0031)\end{array}$ & & & \\
\hline \multicolumn{2}{|l|}{$\Delta_{12-\min } \%$ value added tradable } & & & 0.0090 & & \\
\hline \multicolumn{2}{|l|}{ sectors $_{C}$} & & & $(0.0107)$ & & \\
\hline \multicolumn{2}{|l|}{$\Delta_{12-\min }$ employment protection } & & & & $-0.1185^{* *}$ & \\
\hline \multicolumn{2}{|l|}{ legislation $_{c}$} & & & & $(0.0551)$ & \\
\hline \multirow[t]{2}{*}{$\Delta_{12-\min }$ trade union density ${ }_{c}$} & & & & & & 0.0053 \\
\hline & & & & & & $(0.0075)$ \\
\hline \multirow[t]{2}{*}{ Constant } & 0.0097 & 0.0126 & 0.0105 & 0.0050 & 0.0010 & 0.0034 \\
\hline & $(0.0142)$ & $(0.0130)$ & $(0.0159)$ & $(0.0155)$ & $(0.0123)$ & $(0.0149)$ \\
\hline Observations & 23 & 23 & 23 & 22 & 20 & 19 \\
\hline Adjusted $R$-squared & 0.16 & 0.17 & 0.13 & 0.18 & 0.25 & 0.18 \\
\hline
\end{tabular}

to the mean) of the change in the CAPB and the change in the wage gap. Note that the slope is affected by the huge improvement in the CAPB of Greece, of more than 10 percentage points above the average. If Greece is removed from the regression, the point estimate is even lower $(-0.0092)$, although its statistical significance decreases (to a $p$ value of 0.08 ).

The association between the improvement in the CAPB and the evolution of the pay gap can be explained, at least to some extent, by the discretionary actions taken by governments during this period. ${ }^{28}$ For example, five of the six countries that experienced the largest decreases in the pay gap adopted public wage cuts during the crisis: Greece (2010-2014), Slovenia (2012-2014), Spain (2012-2014), Latvia (2009-2010), and Portugal (2011-2014). In contrast, increases in the wage gap during this period were more likely in countries with no measures regarding public wages (Germany and Lithuania) or wage freezes (France and Belgium). There are two countries that deviate from this pattern. On the one hand, Hungary experienced a sharp decrease in the pay gap, despite resorting only to wage growth controls in 2007-2008. On the other hand, Cyprus implemented wage freezes and cuts during 2011-2014, and still, the estimated wage gap increased by a substantial amount. As mentioned before, these patterns can be the result of outweighing developments in the private sector.

Columns (2) to (6) of Table 4 explores whether the variables that explain the heterogeneity in the levels of the wage gap can also account for the evolution during the crisis. It turns out that no variable enters significantly, suggesting that their effects are mainly felt in the long run. The only exception is the employment protection legislation, which enters significantly but with an opposite sign (more labor protection being associated 
with a lower wage gap). This result, which is at odds with theory, is driven by two countries, Estonia and Slovakia, which elicited legislation to reduce the protection of workers, but at the same time experienced increases in the public pay gap.

\section{Long-run determinants of the public pay gap}

To identify the long-run determinants of the dynamics of the public pay gap, we run the following regression:

$$
\Delta \text { Wage } \operatorname{Gap}_{c t}=\beta^{\prime} \Delta X_{c t}^{\prime}+\sum_{t} \lambda_{t}+\epsilon_{c t}
$$

where $\Delta$ Wage $\operatorname{Gap}_{c t}$ is the change in the macro wage gap between $t$ and $t-1 ; \Delta X_{c t}$ are changes in possible determinants of the dynamics of the wage gap, namely percentage of public employees, openness, share of public employees in Public Administration, government effectiveness, employment protection, and trade union density; and $\sum_{t} \lambda_{t}$ are period fixed effects. The estimation is carried out by pooled OLS. Following the literature on growth, in order to remove the effects of the business cycle, each period is a 5 -year average.

Table 5 shows the results. In column (1), we start by studying the relationship between the dynamics of the wage gap and those of the size of the public labor force and exposure to trade. The availability of data for these two variables allows us to estimate the regression covering the whole period 1975 to 2014 (eight 5 -year periods). We find that increases in the size of the labor force and in exposure to foreign competition are significantly

Table 5 Long-run determinants of the public pay gap

\begin{tabular}{|c|c|c|c|c|c|c|}
\hline & (1) & (2) & (3) & (4) & $(5)$ & (6) \\
\hline \multicolumn{7}{|c|}{ Dep. variable: $\Delta$ general government sector "macro" wage gap $c$ } \\
\hline$\Delta \%$ public employees $_{c t}$ & $\begin{array}{l}-0.0178^{* * *} \\
(0.0068)\end{array}$ & $\begin{array}{l}-0.0087 \\
(0.0183)\end{array}$ & $\begin{array}{l}-0.0180^{* *} \\
(0.0089)\end{array}$ & $\begin{array}{l}-0.0340^{* *} \\
(0.0162)\end{array}$ & $\begin{array}{l}-0.0131 \\
(0.0112)\end{array}$ & $\begin{array}{l}-0.0336^{*} \\
(0.0176)\end{array}$ \\
\hline$\Delta$ Openness $_{C t}$ & $\begin{array}{l}-0.0016^{* *} \\
(0.0007)\end{array}$ & $\begin{array}{l}-0.0021^{* *} \\
(0.0010)\end{array}$ & $\begin{array}{l}-0.0016^{* *} \\
(0.0008)\end{array}$ & $\begin{array}{l}-0.0020^{* * *} \\
(0.0006)\end{array}$ & $\begin{array}{l}-0.0005 \\
(0.0015)\end{array}$ & $\begin{array}{l}-0.0019^{* *} \\
(0.0007)\end{array}$ \\
\hline $\begin{array}{l}\Delta \% \text { public administration } \\
\text { employees }_{c t}\end{array}$ & & $\begin{array}{l}1.4048 \\
(1.3675)\end{array}$ & & & & \\
\hline$\Delta$ Quality of government $c t$ & & & $\begin{array}{l}-0.2457^{*} \\
(0.1320)\end{array}$ & & & \\
\hline$\Delta$ Government effectiveness $_{c t}$ & & & & $\begin{array}{l}-0.1631^{* *} \\
(0.0630)\end{array}$ & & \\
\hline $\begin{array}{l}\Delta \text { Employment protection } \\
\text { legislation }_{c t}\end{array}$ & & & & & $\begin{array}{l}0.0699 \\
(0.1028)\end{array}$ & \\
\hline$\Delta$ Trade union density ${ }_{c t}$ & & & & & & $\begin{array}{l}-0.0023 \\
(0.0059)\end{array}$ \\
\hline 5-year dummies & Yes & Yes & Yes & Yes & Yes & Yes \\
\hline Time period & $1975-2014$ & 1980-2014 & $1985-2014$ & $2000-2014$ & 1990-2014 & 2000-2014 \\
\hline Observations & 146 & 56 & 110 & 57 & 91 & 57 \\
\hline Adjusted $R$-squared & 0.28 & 0.13 & 0.21 & 0.36 & 0.17 & 0.28 \\
\hline
\end{tabular}

Notes: This table shows the regression of 5 -year changes in the macro wage gap on 5 -year changes of country characteristics linked to the government monopolistic power in the provision of public services and labor market institutions (long-run determinants of the public pay gap, Eq. (2)). Robust standard errors are in parenthesis

Significance levels: ${ }^{* 10} \% ; * * 5 \% ; * * 1 \%$ 
associated with reductions in the public sector pay gap. The point estimates suggest that an increase of one standard deviation in the change of the percentage of public employees (1.5 percentage points) is associated with a decrease of 2.7 percentage points ( 0.29 standard deviations) in the change of the wage gap. Also, an increase of one standard deviation in the change of the openness ratio (9.4 percentage points) is associated with a decrease of 1.6 percentage points (.17 standard deviations) in the change of the wage gap. This last association is very robust to different specifications, whereas the relationship between the percentage of public employees and the wage gap, although always negative, is somewhat less stable (see the following columns). In column (2), we include as an additional determinant the first difference of the share of public workers that work in Public Administration. The lower availability of data for this variable reduces our estimation to a shorter time period and therefore decreases considerably the number of observations. The point estimate suggests that increases in this ratio are associated with increases in the wage gap, but opposite to the cross-sectional regressions, the relationship is not statistically significant ( $p$ value is 0.31 ). In column (3), we include the first difference of an index of government quality (the International Country Risk Guide Indicator of Quality of Government), which captures the level of efficiency of the public sector. This index has the advantage that is available for all countries in our sample and for a long time period (1984-2012). We see that improvements in the quality of government are associated with lower wage gaps (in first differences). A one standard deviation increase in the change of government quality is associated with a 2.7 percentage point decrease in the change of the pay gap, which is 0.34 standard deviations, being this relationship statistically significant. Moreover, this relationship holds when we use an alternative measure of the quality of the public sector, the index of government effectiveness of the Worldwide Governance Indicators; see column (4). In this case, a one standard deviation increase in the change of government quality is associated with a significant 2.6 percentage point decrease in the change of the

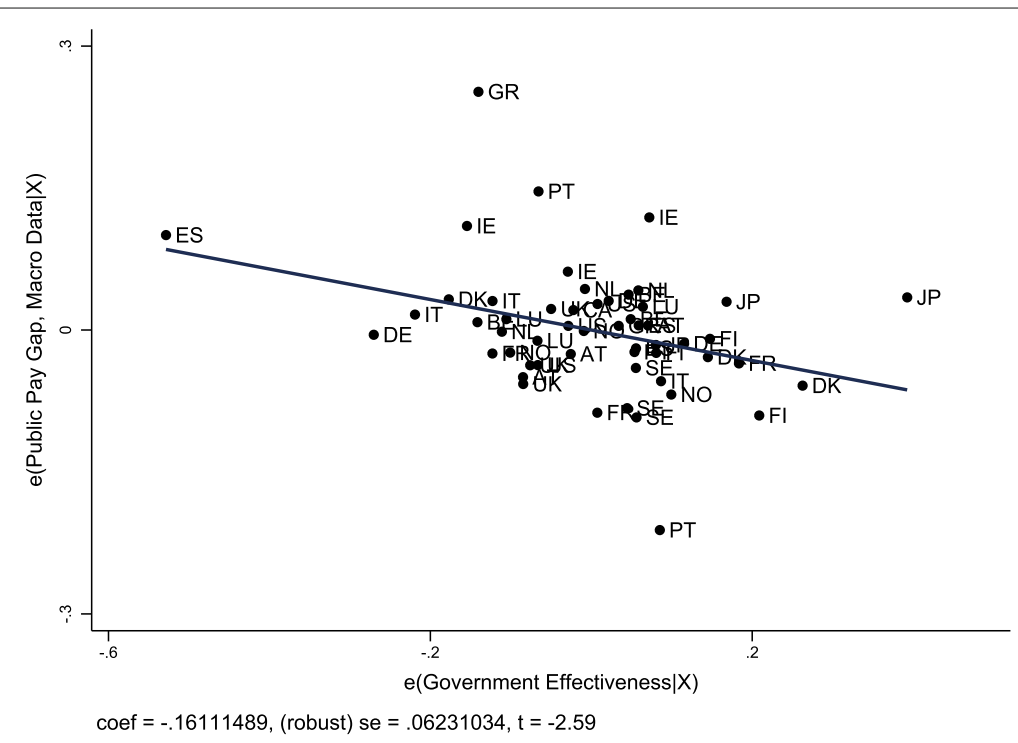

Fig. 4 Partial correlation between government effectiveness and the public pay gap. Notes: This figure shows the correlation between 5 -year changes in the quality of public services of a country and changes in the public sector pay gap, once other characteristics are controlled for, namely changes in the number of public employees and changes in openness; see column (4) of Table 5. The negative slope indicates that improvements in the quality of public services are associated in the long run with lower public sector pay gaps 
pay gap, which is 0.33 standard deviations. ${ }^{29}$ Figure 4 shows that this association is not driven by outliers, although the estimation comprises just three time periods. Moreover, the association between improvements in government quality (including either indicator) and decreases in the pay gap is robust to include country fixed effects in the change of the wage gap (not shown). With respect to the variables linked to wage-setting institutions, employment protection and trade union density, we find no statistical relationship with respect to the wage gap; see columns (5) and (6). Although the sign of employment protection is positive, it lacks statistical significance, whereas changes of trade union density are estimated to be uncorrelated with changes in the wage gap. Overall, this long-run analysis corroborates the importance of accounting for the government monopolistic power in explaining the wage gap. From a long time period perspective, increases in foreign competition and improvements in the institutional quality of governments are associated with significant reductions in the public sector pay gap. The evidence also suggests that increases in the number of employees are also associated with reductions in the public sector pay gap, but in this case, the estimates are more noisy.

In Table 6, we test that our strategy to take 5-year averages effectively removed the effects of the business cycle. We add as additional determinants to the change in the wage gap the first difference of several proxies of economic conditions, namely real GDP, the general government deficit, the level of public debt, and the unemployment rate. None of these variables enter significantly in either regression, whereas the coefficients of percentage of public employees, openness, and government effectiveness remain stable and statistically significant, the only exception being the coefficient of government quality

Table 6 Long-run determinants of the public pay gap: robustness

\begin{tabular}{|c|c|c|c|c|}
\hline & $(1)$ & $(2)$ & (3) & (4) \\
\hline \multicolumn{5}{|c|}{ Dep. variable: $\Delta$ general government sector "macro" wage gap $c t$} \\
\hline \multirow{2}{*}{$\Delta \%$ public employees ${ }_{c t}$} & $-0.0184^{* *}$ & $-0.0223^{* *}$ & $-0.0194^{*}$ & $-0.0208^{* *}$ \\
\hline & $(0.0087)$ & $(0.0099)$ & $(0.0101)$ & $(0.0100)$ \\
\hline \multirow[t]{2}{*}{$\Delta$ Openness $_{c t}$} & $-0.0015^{*}$ & $-0.0016^{*}$ & $-0.0016^{*}$ & $-0.0016^{*}$ \\
\hline & $(0.0008)$ & $(0.0008)$ & $(0.0009)$ & $(0.0008)$ \\
\hline \multirow{2}{*}{$\Delta$ Quality of government ${ }_{c t}$} & $-0.2381^{*}$ & $-0.2539^{*}$ & $-0.3421^{* *}$ & -0.1888 \\
\hline & $(0.1301)$ & $(0.1485)$ & $(0.1317)$ & $(0.1447)$ \\
\hline \multirow[t]{2}{*}{$\Delta$ Log real GDP $c t$} & -0.0607 & & & \\
\hline & $(0.1242)$ & & & \\
\hline \multirow[t]{2}{*}{$\Delta$ Deficit $_{c t}$} & & 0.0035 & & \\
\hline & & $(0.0047)$ & & \\
\hline \multirow[t]{2}{*}{$\Delta$ Debt $_{c t}$} & & & -0.0001 & \\
\hline & & & $(0.0007)$ & \\
\hline \multirow[t]{2}{*}{$\Delta$ Unemployment rate $_{c t}$} & & & & 0.0051 \\
\hline & & & & $(0.0065)$ \\
\hline 5-year dummies & Yes & Yes & Yes & Yes \\
\hline Time period & 1985-2014 & $1985-2014$ & $1985-2014$ & 1985-2014 \\
\hline Observations & 110 & 99 & 94 & 102 \\
\hline Adjusted R-squared & 0.20 & 0.22 & 0.21 & 0.21 \\
\hline
\end{tabular}

Notes: This table shows the regression of 5-year changes in the macro wage gap on 5-year changes on country characteristics linked to the government monopolistic power in the provision of public services and business cycle variables. Robust standard errors are in parenthesis

Significance levels: *10\%; ** $5 \%$; ***1\% 
in column (4), with a $p$ value of 0.19 . This reassures the robustness of the association between the dynamics of the government sector and the public pay gap.

\section{Conclusions}

In this paper, we provide descriptive evidence on the determinants of the levels and dynamics of the public pay premia in a large set of mostly EU countries. We show three results. First, more than half of the cross-sectional variation in public pay gaps can be accounted for by the size and composition of the public labor force, as well as exposure to international competition. Second, the evolution of the gap during the recent financial crisis is significantly explained by improvements in fiscal positions. Third, openness to international trade and improvements in the quality of governments have been associated in the long run with decreases in the public pay gap.

These findings are rationalized by an extensive body of research that stresses that the noncompetitive environment in which the government sector operates is at the root of the higher earnings enjoyed in the public sector. Given the important effects this has on the labor market and the competitiveness of countries, our findings shed some light on the source of these inefficiencies and help policy makers design public wage bill policies aimed at providing the correct incentives, improve overall efficiency, and achieve fiscal soundness.

\section{Endnotes}

${ }^{1}$ See, for instance, Holm-Hadulla F et al. (2010) and European Commission (2014). On the more general issue of public employment and compensation reform, see Forni and Novta N (2016).

${ }^{2}$ An overwhelming majority of the literature looks at wage level differentials. Nevertheless, some papers look at lifetime values of employment between public and private sectors, such as Dickson et al. (2014). These authors look at lifetime values instead of wage levels because they claim that differences in earnings mobility, earnings volatility, and job risk across sectors occur in many instances and may matter to forward-looking individuals.

${ }^{3}$ For some recent contributions to a fast expanding literature, see Giordano et al. (2015), Depalo et al. (2015), Lausev (2014), European Commission (2014), or Christofides and Michael (2013) and the references quoted therein. On related grounds, a strand of the literature looks at the "politicians' pay gap" (see in particular Peichl et al. (2013), for the case of Germany).

${ }^{4}$ See for instance Holm-Hadulla F et al. (2010) and the references quoted therein.

${ }^{5}$ More recently, Cavalcanti and Rodrigues dos Santos (2015) develop an equilibrium model with endogenous occupational choice among the public and the private sectors, in which a public-private earnings premium is characterized. They calibrate the model to the Brazilian economy. They show that the presence of a public-private earnings premium can generate important allocation effects in the economy and sizable productive losses.

${ }^{6}$ See Fernández-de-Córdoba et al. (2012) or Kollintzas et al. (2015). On related grounds, on the appropriation of resources by the bureaucracy in the form of higher wages, see Marconi et al. (2009).

${ }^{7}$ See, for example, Alesina et al. (2000).

${ }^{8}$ See, for example, Matschke (2003). 
${ }^{9}$ It has also been argued on theoretical grounds (Becker and Stigler (1974)) that the public wage premium may serve as an effective policy to fight corruption. Nevertheless, as discussed by Marconi et al. (2009), this is hard to justify for two main reasons. First, governments own other instruments to fight corruption. Second, the fight against a high degree of corruption could demand a much larger budget.

${ }^{10}$ See, for example, Visser (2013).

${ }^{11}$ See, for instance, Holmlund (1993) and Holmlund (1997).

${ }^{12}$ See, for instance, Caponi (2014).

${ }^{13}$ See the stylized facts presented by Fernández-de-Córdoba et al. (2012) and Kollintzas et al. (2015).

${ }^{14}$ According to ESA 2010, the general government sector consists of "institutional units which are nonmarket producers whose output is intended for individual and collective consumption, and are financed by compulsory payments made by units belonging to other sectors, and institutional units principally engaged in the redistribution of national income and wealth." As such, the nonmarket activities O, P, and Q represent the best proxy for the general government sector when this indicator is not provided. Having said this, it is worth noting that it is not possible to carry out a broad check on how well these nonmarket activities encompass general government employees, due to the lack of across-countries homogeneous datasets. Indeed, there exists heterogeneity across countries in the public sector involvement in the different sectors of the economy. For example, according to Danmarks Statistik and the Spanish Labour Force Survey, while in Denmark, the number of general government employees in the Health and Education sectors is close to $90 \%$ and more than $80 \%$, respectively; in Spain, these percentages are about 50 and $60 \%$, respectively. On the contrary, the vast majority of workers in sector $\mathrm{O}$ are public sector employees: 94 and 97\% in Denmark and Spain, respectively.

${ }^{15}$ It must be stressed that there may be other relevant characteristics that affect the wage differential. In particular, in this study, data limitations prevent us to control for a number of factors: among others, fringe benefits (which are typically higher in the private sector) and pension rights (generally higher in the public sector), but also non-monetary factors, such as job security that is generally larger in the public sector. Finally, our data do not allow to control for the sample selection bias due to the possibility that sorting of employees between sectors is not random but occurs on the basis of unobserved characteristics. All this said, it has to be mentioned that the bulk of our results is in line with previous country-specific analyses with finer data (for a recent contribution, see Hospido and Moral-Benito (2014) and the references quoted therein). For more details, see Giordano et al. (2015) and Depalo et al. (2015).

${ }^{16}$ Other approaches to measure unexplained gaps in mean outcomes comprise the socalled Oaxaca-Blinder decomposition, see Oaxaca (1973) and Blinder (1973), and the alternative proposed by Neumark (1988). We follow the approach of a dummy indicator for convenience and because it tends to be bounded by the two standard Oaxaca-Blinder gaps. Moreover, the Neumark (1988) approach systematically overstates the contribution of observables to mean outcome differences. For a discussion on these four approaches, see Elder et al. (2010).

${ }^{17}$ Nevertheless, it is worth mentioning that while the choice of macro data sources and definitions insures the best available degree of harmonization and comparability, there might be measurement problems both within and across countries. Differences/changes 
in working hours, privatization, differences/changes in the size of the public sector over time, or changes in the skill composition of the labor force over time might distort the view on certain issues.

${ }^{18}$ One country, Luxembourg, significantly deviates: it has a large micro wage gap and a below-average macro gap. For the sake of transparency, we decided not to drop this country from the sample. The results are qualitatively very similar had we chosen to do so (first-differencing removes the largest part of the bias).

${ }^{19}$ The main theoretical reference is the Scandinavian model of inflation, see Lindquist and Vilhelmsson (2006), where the traded-goods sector exerts a "leadership" or "signaling" role which can hold sway on public sector wages. Moreover, Lamo et al. (2013) show that, in the long run, private wages tend to lead public wages and that the probability of this happening is more likely the greater is the openness to international trade.

${ }^{20}$ Note that the dependent variable is estimated from micro data, and hence, it is subject to uncertainty. We make the assumption that the noise induced by the estimation is uncorrelated with the country characteristics, and hence, this noise only yields higher standard errors, which go against finding a significant relationship between the covariates and the dependent variable. This seems reasonable, as Eurostat provides a common framework for the EU-SILC database. Note also that some of the country characteristics are also obtained from EU-SILC (e.g., the percentage of public employees). For the same reason, it is reasonable to assume that the possible measurement error is uncorrelated with the observed covariates, yielding again only higher variances. Moreover, we try alternative specifications with additional data sources when this is possible, to check the robustness of the results. In any case, we are aware of the difficulties of giving a causal interpretation to the coefficients, as orthogonality between the covariates and the error term is clearly not guaranteed. Our focus is on checking the cross-country implications of the theories explaining the wage gap, and we favor a prudent predictive interpretation of our results.

${ }^{21}$ That is, we show the scatterplot of the unexplained part of the dependent variable and the unexplained part of each covariate of column (2), where the unexplained part is given by the residuals of the regression on the other covariates. For example, the partial correlation of the wage gap and the share of public employees (Fig. 3a) is constructed as follows. First, regress the wage gap on the share of public employees in industry $\mathrm{O}$ and the share of tradable sectors in total value added (the other two covariates of column (2)), and obtain the residuals. Second, regress the share of public employees on the share of public employees in industry $\mathrm{O}$ and the share of tradable sectors in total value added, and obtain the residuals. Third, plot both series of residuals. Note that the slope of the scatterplot is precisely the coefficient reported in column (2) of Table 2, and hence, the picture allows to determine the existence of outliers driving the estimates. Note also that Fig. $3 \mathrm{~d}-\mathrm{f}$ show partial correlations of bivariate relationships; hence, they are just simple scatterplots in deviations with respect to the mean.

${ }^{22}$ We use the index average of 2003, 2008, and 2013. Arguably, in order to proxy for competitiveness, one would prefer to add outcome variables, rather than a proxy of regulation, but competition outcomes that are truly comparable (in levels) across countries are to the best of our knowledge not available.

${ }^{23}$ The results are not shown for the sake of brevity but are presented in Table 9 of Appendix 2. We further check the robustness of these results by incorporating additional 
explanatory variables with potential in explaining the cross-country variation in wage gaps. In particular, we add different proxies of economic conditions, such as per capita GDP, the general government deficit, the level of debt, and real GDP growth. It turns out that only the general government deficit has some significant explanatory power in accounting for the variation in the public pay gaps, and in all specifications, the size and composition of the public workforce, as well as exposure to foreign competition, keep their statistical significance.

${ }^{24}$ See Table 10 of Appendix 2.

${ }^{25}$ Results are shown in Table 11 of the Appendix 2.

${ }^{26}$ The gap for female workers is computed by estimating Eq. (1) for the sample of females. The gap at the first quartile of the income distribution is computed via a quantile regression with the same covariates as Eq. (1).

${ }^{27}$ We also tried running these specifications exploiting the panel structure of EU-SILC (2004-2012) with country fixed effects and with/without a lag of the public pay gap. These regressions did not deliver meaningful estimates, probably due to the fact that changes in the structural characteristics of the public labor force take some time to be reflected on the public pay gap. For this reason, we view the long-run regressions performed in Section 4 as more likely to capture the dynamic relationship between the structural characteristics of a country and the pay gap. Moreover, we find evidence that the recent evolution of the pay gap is explained by the process of fiscal consolidation, rather than by the changes in the factors with explanatory power in the cross section; see Section 3.2.

${ }^{28}$ See Appendix IIIa of Pérez JJ et al. (2016).

${ }^{29}$ Kaufmann et al. (2010) note that the Worldwide Governance Indicators use reasonably comparable methodologies over time, then the indicators can be meaningfully compared both across countries and over time.

\section{Appendix 1}

Data: definitions and sources

Table 7 Data: definitions and sources

\begin{tabular}{|c|c|c|}
\hline Variable & Source & Definition \\
\hline $\begin{array}{l}\% \text { of public } \\
\text { employees }\end{array}$ & EU-SILC & $\begin{array}{l}\text { Number of employees in industries O, P, Q (Nace Rev. 2) } \\
\text { over total number of employees }\end{array}$ \\
\hline $\begin{array}{l}\% \text { of public } \\
\text { administration } \\
\text { employees }\end{array}$ & EU-SILC & $\begin{array}{l}\text { Number of employees in industry O (Nace Rev. 2) over } \\
\text { total number of public employees }\end{array}$ \\
\hline $\begin{array}{l}\text { Government } \\
\text { effectiveness }\end{array}$ & $\begin{array}{l}\text { Worldwide Governance } \\
\text { Indicators }\end{array}$ & $\begin{array}{l}\text { Government effectiveness captures perceptions of the } \\
\text { quality of public services, the quality of the civil service and } \\
\text { the degree of its independence from political pressures, } \\
\text { the quality of policy formulation and implementation, and } \\
\text { the credibility of the government's commitment to such } \\
\text { policies. }\end{array}$ \\
\hline $\begin{array}{l}\% \text { of value added in } \\
\text { tradable sectors }\end{array}$ & Eurostat & $\begin{array}{l}\text { Gross value added in agriculture and manufacturing over } \\
\text { total gross value added. }\end{array}$ \\
\hline $\begin{array}{l}\% \text { of public } \\
\text { employees (over } \\
\text { population) }\end{array}$ & EU-SILC and Eurostat & $\begin{array}{l}\text { Number of employees in industries } \mathrm{O}, \mathrm{P}, \mathrm{Q} \text { (Nace Rev. 2) } \\
\text { over population. }\end{array}$ \\
\hline $\begin{array}{l}\% \text { of compensation } \\
\text { of employees in } \\
\text { collective goods }\end{array}$ & Eurostat (COFOG) & $\begin{array}{l}\text { Total general government (GG) compensation of } \\
\text { employees minus GG compensation of employees in } \\
\text { health, education and social protection. }\end{array}$ \\
\hline Openness & World Bank & Exports plus imports over GDP. \\
\hline
\end{tabular}


Table 7 Data: definitions and sources (Continued)

\begin{tabular}{|c|c|c|}
\hline $\begin{array}{l}\text { Product market } \\
\text { regulation }\end{array}$ & OECD & $\begin{array}{l}\text { Index that measures the degree to which policies } \\
\text { promote or inhibit competition in areas of the product } \\
\text { market where competition is viable. }\end{array}$ \\
\hline $\begin{array}{l}\text { Employment } \\
\text { protection legislation }\end{array}$ & OECD & $\begin{array}{l}\text { Indicator of the procedures and costs involved in } \\
\text { dismissing individuals and groups of workers. We use } \\
\text { version } 2 \text { of the indicator (1998-2013) for the } \\
\text { cross-section regressions and version } 1 \text { (1985-2013) for } \\
\text { the long-run regressions. }\end{array}$ \\
\hline $\begin{array}{l}\text { Trade union } \\
\text { density }\end{array}$ & OECD and Visser (2013) & $\begin{array}{l}\text { Ratio of wage and salary earners that are trade union } \\
\text { members, divided by the total number of wage and } \\
\text { salary earners. }\end{array}$ \\
\hline $\begin{array}{l}\text { Coverage of } \\
\text { collective } \\
\text { bargaining }\end{array}$ & Visser (2013) & $\begin{array}{l}\text { Employees covered by collective (wage) bargaining } \\
\text { agreements as a proportion of all wage and salary earners } \\
\text { in employment with the right to bargaining, adjusted for } \\
\text { the possibility that some sectors or occupations are } \\
\text { excluded from the right to bargain. }\end{array}$ \\
\hline Bargaining & $\begin{array}{l}\text { Table } 2 \text { of European } \\
\text { Commission (2014) }\end{array}$ & $\begin{array}{l}\text { The predominant regime of wage setting in the } \\
\text { government sector is collective bargaining as opposed } \\
\text { to unilateral decision. }\end{array}$ \\
\hline Centralization & $\begin{array}{l}\text { Table } 2 \text { of European } \\
\text { Commission (2014) }\end{array}$ & $\begin{array}{l}\text { There is de jure centralization of wage updates across } \\
\text { the government sector as opposed to decentralization. }\end{array}$ \\
\hline Log per capita GDP & Eurostat & $\begin{array}{l}\text { Gross domestic product, chain linked volumes (2010), euro } \\
\text { per capita. }\end{array}$ \\
\hline Deficit & IMF and ECB & $\begin{array}{l}\text { General government deficit (excluding the government } \\
\text { assistance to the financial sector). }\end{array}$ \\
\hline Debt & IMF & General government gross debt. \\
\hline Real GDP growth & Eurostat & $\begin{array}{l}\text { Percentage change of gross domestic product, chain } \\
\text { linked volumes (2010). }\end{array}$ \\
\hline $\begin{array}{l}\text { Cyclically adjusted } \\
\text { primary balance } \\
\text { (CAPB) }\end{array}$ & $\begin{array}{l}\text { European Commission } \\
\text { and ECB }\end{array}$ & $\begin{array}{l}\text { Cyclically adjusted primary balance excluding } \\
\text { government assistance to the financial sector. }\end{array}$ \\
\hline $\begin{array}{l}\% \text { of public } \\
\text { employees (long-run } \\
\text { regressions) }\end{array}$ & OECD & $\begin{array}{l}\text { Number of employees in the general government sector } \\
\text { over total number of employees }\end{array}$ \\
\hline $\begin{array}{l}\text { \% of public } \\
\text { administration } \\
\text { employees (long-run } \\
\text { regressions) }\end{array}$ & Eurostat & $\begin{array}{l}\text { Number of employees in Public Administration over total } \\
\text { number employees in Public Administration, Education, } \\
\text { and Health. }\end{array}$ \\
\hline $\begin{array}{l}\text { Quality of } \\
\text { government }\end{array}$ & $\begin{array}{l}\text { International Country } \\
\text { Risk Guide (ICRG) and } \\
\text { Teorell et al. (2015) }\end{array}$ & $\begin{array}{l}\text { The mean value of the ICRG variables "Corruption," "Law } \\
\text { and Order," and "Bureaucracy Quality," where higher } \\
\text { values indicate higher quality of government. Corruption } \\
\text { is an assessment of corruption in the political system. Law } \\
\text { and Order assesses the strength and impartiality of the } \\
\text { legal system as well as the popular observance of the } \\
\text { law. Bureaucratic Quality measures the institutional } \\
\text { strength and quality of the bureaucracy. }\end{array}$ \\
\hline Unemployment rate & Eurostat & Unemployment rate, annual average. \\
\hline
\end{tabular}

\section{Appendix 2}

\section{Additional robustness checks of the cross-country determinants of the public pay gap}

Table 8 Bivariate relationships between the government monopolistic power and the wage gap

\begin{tabular}{llll}
\hline (1) & (2) & (3)
\end{tabular}

Dep. variable: NACE proxy to government sector wage gap (2004-2012)

$\%$ Public employees $\quad-0.0143^{* * *}$

(0.0046)

\% Public administration $\quad 0.0107^{* * *}$

employees (0.0027)

Government effectiveness $\quad-0.1077^{* * *}$

(0.0362)

$\%$ Value added tradable 
Table 8 Bivariate relationships between the government monopolistic power and the wage gap (Continued)

\begin{tabular}{|c|c|c|c|c|}
\hline \multicolumn{4}{|l|}{ Sectors } & \multirow{2}{*}{$\begin{array}{l}(0.0055) \\
0.1700\end{array}$} \\
\hline Constant & $0.4991^{* * *}$ & $-0.2652^{* * *}$ & $0.2248^{* * *}$ & \\
\hline & $(0.1340)$ & $(0.0826)$ & (0.0398) & $(0.1150)$ \\
\hline Observations & 25 & 25 & 25 & 24 \\
\hline$R$-squared & 0.33 & 0.47 & 0.19 & 0.04 \\
\hline
\end{tabular}

Notes: This table shows the bivariate regressions of the public sector pay gap on country characteristics linked to the government monopolistic power in the provision of public services. Robust standard errors are in parenthesis

Significance levels: $* 10 \% ; * * 5 \% ; * * 1 \%$

Table 9 Determinants of the public sector pay gap: government monopolistic power and wage-setting institutions

(1) (2) $\quad$ (3) $\quad$ (4) $\quad$ (5)

Dep. variable: NACE proxy to government sector wage gap (2004-2012)

\begin{tabular}{|c|c|c|c|c|c|c|}
\hline \% Public employees & $\begin{array}{l}-0.0092^{* *} \\
(0.0041)\end{array}$ & $\begin{array}{l}-0.0091 \\
(0.0056)\end{array}$ & $\begin{array}{l}-0.0121^{* *} \\
(0.0043)\end{array}$ & $\begin{array}{l}-0.0110^{* * *} \\
(0.0036)\end{array}$ & $\begin{array}{l}-0.0113^{* *} \\
(0.0049)\end{array}$ & $\begin{array}{l}-0.0110^{* *} \\
(0.0041)\end{array}$ \\
\hline $\begin{array}{l}\text { \% Public administration } \\
\text { employees }\end{array}$ & $\begin{array}{l}0.0071^{* *} \\
(0.0025)\end{array}$ & $\begin{array}{l}0.0065^{* *} \\
(0.0029)\end{array}$ & $\begin{array}{l}0.0078^{* * *} \\
(0.0024)\end{array}$ & $\begin{array}{l}0.0045^{*} \\
(0.0026)\end{array}$ & $\begin{array}{l}0.0072^{* *} \\
(0.0028)\end{array}$ & $\begin{array}{l}0.0073^{* * *} \\
(0.0021)\end{array}$ \\
\hline $\begin{array}{l}\% \text { Value added tradable } \\
\text { sectors }\end{array}$ & $\begin{array}{l}-0.0078^{* *} \\
(0.0037)\end{array}$ & $\begin{array}{l}-0.0083^{*} \\
(0.0040)\end{array}$ & $\begin{array}{l}-0.0075^{*} \\
(0.0038)\end{array}$ & $\begin{array}{l}-0.0099^{* * *} \\
(0.0033)\end{array}$ & $\begin{array}{l}-0.0087^{* *} \\
(0.0032)\end{array}$ & $\begin{array}{l}-0.0082^{* *} \\
(0.0033)\end{array}$ \\
\hline $\begin{array}{l}\text { Employment protection } \\
\text { legislation }\end{array}$ & $\begin{array}{l}0.0298 \\
(0.0540)\end{array}$ & & & & & \\
\hline Trade union density & & $\begin{array}{l}-0.0008 \\
(0.0014)\end{array}$ & & & & \\
\hline Log per capita GDP & & & $\begin{array}{l}0.0265 \\
(0.0419)\end{array}$ & & & \\
\hline Deficit & & & & $\begin{array}{l}0.0081^{*} \\
(0.0044)\end{array}$ & & \\
\hline Debt & & & & & $\begin{array}{l}0.0001 \\
(0.0005)\end{array}$ & \\
\hline Real GDP growth & & & & & & $\begin{array}{l}-0.0081 \\
(0.0113)\end{array}$ \\
\hline Constant & $\begin{array}{l}0.1738 \\
(0.2051)\end{array}$ & $\begin{array}{l}0.3063 \\
(0.2130)\end{array}$ & $\begin{array}{l}0.0482 \\
(0.5080)\end{array}$ & $\begin{array}{l}0.4225^{* *} \\
(0.1850)\end{array}$ & $\begin{array}{l}0.3232 \\
(0.2225)\end{array}$ & $\begin{array}{l}0.3244 \\
(0.1928)\end{array}$ \\
\hline Observations & 22 & 21 & 24 & 23 & 24 & 24 \\
\hline Adjusted $R$-squared & 0.48 & 0.49 & 0.59 & 0.62 & 0.58 & 0.59 \\
\hline
\end{tabular}

Notes: This table shows the regression of the public sector pay gap on country characteristics linked to the government monopolistic power in the provision of public services, the labor market institutions, and the business cycle. Robust standard errors are in parenthesis

Significance levels: *10\%; **5\%; *** $1 \%$ 
Table 10 Determinants of the public sector pay gap: sample 2004-2007

\begin{tabular}{|c|c|c|c|c|c|c|}
\hline & (1) & (2) & (3) & (4) & (5) & (6) \\
\hline \multicolumn{7}{|c|}{ Dep. variable: NACE proxy to government sector wage gap (2004-2007) } \\
\hline \% Public employees & $\begin{array}{l}-0.0118^{* * *} \\
(0.0036)\end{array}$ & $\begin{array}{l}-0.0086^{* *} \\
(0.0040)\end{array}$ & $\begin{array}{l}-0.0111^{* * *} \\
(0.0036)\end{array}$ & $\begin{array}{l}-0.0110^{\text {*** }} \\
(0.0030)\end{array}$ & $\begin{array}{l}-0.0107^{* * *} \\
(0.0037)\end{array}$ & $\begin{array}{l}-0.0112^{* * *} \\
(0.0031)\end{array}$ \\
\hline $\begin{array}{l}\text { \% Public administration } \\
\text { employees }\end{array}$ & $\begin{array}{l}0.0056^{* *} \\
(0.0022)\end{array}$ & $\begin{array}{l}0.0069^{* *} \\
(0.0025)\end{array}$ & $\begin{array}{l}0.0080^{* * *} \\
(0.0022)\end{array}$ & $\begin{array}{l}0.0060^{* *} \\
(0.0025)\end{array}$ & $\begin{array}{l}0.0080^{* * *} \\
(0.0025)\end{array}$ & $\begin{array}{l}0.0078^{* * *} \\
(0.0020)\end{array}$ \\
\hline $\begin{array}{l}\% \text { Value added tradable } \\
\text { sectors }\end{array}$ & $\begin{array}{l}-0.0058^{*} \\
(0.0028)\end{array}$ & $\begin{array}{l}-0.0070^{* *} \\
(0.0032)\end{array}$ & $\begin{array}{l}-0.0061^{*} \\
(0.0030)\end{array}$ & $\begin{array}{l}-0.0076^{* *} \\
(0.0028)\end{array}$ & $\begin{array}{l}-0.0065^{* *} \\
(0.0025)\end{array}$ & $\begin{array}{l}-0.0063^{* *} \\
(0.0024)\end{array}$ \\
\hline $\begin{array}{l}\text { Employment protection } \\
\text { legislation }\end{array}$ & $\begin{array}{l}0.0268 \\
(0.0421)\end{array}$ & & & & & \\
\hline Trade union density & & $\begin{array}{l}-0.0011 \\
(0.0012)\end{array}$ & & & & \\
\hline Log per capita GDP & & & $\begin{array}{l}0.0076 \\
(0.0453)\end{array}$ & & & \\
\hline Deficit & & & & $\begin{array}{l}0.0031 \\
(0.0040)\end{array}$ & & \\
\hline Debt & & & & & $\begin{array}{l}0.0000 \\
(0.0006)\end{array}$ & \\
\hline Real GDP growth change & & & & & & $\begin{array}{l}-0.0026 \\
(0.0072)\end{array}$ \\
\hline Constant & $\begin{array}{l}0.2748 \\
(0.2025)\end{array}$ & $\begin{array}{l}0.2618 \\
(0.1524)\end{array}$ & $\begin{array}{l}0.1751 \\
(0.4858)\end{array}$ & $\begin{array}{l}0.3510^{* *} \\
(0.1663)\end{array}$ & $\begin{array}{l}0.2478 \\
(0.1729)\end{array}$ & $\begin{array}{l}0.2777^{*} \\
(0.1516)\end{array}$ \\
\hline Observations & 17 & 20 & 24 & 23 & 24 & 24 \\
\hline Adjusted $R$-squared & 0.60 & 0.62 & 0.64 & 0.65 & 0.64 & 0.64 \\
\hline
\end{tabular}

Notes: This table shows the correlation between the public sector pay gap and country characteristics linked to the government monopolistic power in the provision of public services, the labor market institutions, and the business cycle. This is the analog of Table 9 but for the sample 2004-2007 (excluding the crisis years). Robust standard errors are in parenthesis

Significance levels: ${ }^{* 10} \%$; ${ }^{* *} 5 \%$; ${ }^{* *} 1 \%$

Table 11 Determinants of the public administration pay gap

\begin{tabular}{|c|c|c|c|c|c|c|}
\hline & (1) & (2) & (3) & (4) & (5) & (6) \\
\hline \multicolumn{7}{|c|}{ Dep. variable: public administration (industry O) wage gap (2004-2012) } \\
\hline $\begin{array}{l}\text { \% Public administration } \\
\text { employees (over total employees) }\end{array}$ & $\begin{array}{l}-0.0184^{*} \\
(0.0103)\end{array}$ & $\begin{array}{l}-0.0130 \\
(0.0135)\end{array}$ & $\begin{array}{l}-0.0190^{*} \\
(0.0100)\end{array}$ & $\begin{array}{l}-0.0208^{* *} \\
(0.0085)\end{array}$ & $\begin{array}{l}-0.0140 \\
(0.0108)\end{array}$ & $\begin{array}{l}-0.0198^{* *} \\
(0.0088)\end{array}$ \\
\hline $\begin{array}{l}\text { \% Public administration } \\
\text { employees (over public employees) } \\
\% \text { Value added tradable } \\
\text { sectors }\end{array}$ & $\begin{array}{l}0.0086^{* *} \\
(0.0032) \\
-0.0046 \\
(0.0030)\end{array}$ & $\begin{array}{l}0.0056 \\
(0.0050) \\
-0.0041 \\
(0.0037)\end{array}$ & $\begin{array}{l}0.0085^{* * *} \\
(0.0030) \\
-0.0047^{*} \\
(0.0026)\end{array}$ & $\begin{array}{l}0.0074^{* * *} \\
(0.0023) \\
-0.0051^{* *} \\
(0.0021)\end{array}$ & $\begin{array}{l}0.0084^{* * *} \\
(0.0022) \\
-0.0044^{* *} \\
(0.0020)\end{array}$ & $\begin{array}{l}0.0089^{* * *} \\
(0.0022) \\
-0.0045^{*} \\
(0.0023)\end{array}$ \\
\hline $\begin{array}{l}\text { Employment protection } \\
\text { legislation }\end{array}$ & $\begin{array}{l}0.0018 \\
(0.0373)\end{array}$ & & & & & \\
\hline Trade union density & & -0.0010 & & & & \\
\hline Debt & & & & & $\begin{array}{l}-0.0007 \\
(0.0004)\end{array}$ & \\
\hline Real GDP growth & & & & & & $\begin{array}{l}0.0032 \\
(0.0081)\end{array}$ \\
\hline Constant & $\begin{array}{l}0.0818 \\
(0.0880)\end{array}$ & $\begin{array}{l}0.1589 * \\
(0.0858)\end{array}$ & $\begin{array}{l}0.1761 \\
(0.3863)\end{array}$ & $\begin{array}{l}0.1534^{* *} \\
(0.0546)\end{array}$ & $\begin{array}{l}0.0918 \\
(0.0715)\end{array}$ & $\begin{array}{l}0.0881 \\
(0.0676)\end{array}$ \\
\hline Observations & 22 & 21 & 24 & 23 & 24 & 24 \\
\hline Adjusted R-squared & 0.22 & 0.24 & 0.35 & 0.37 & 0.41 & 0.35 \\
\hline
\end{tabular}

Notes: This table shows the correlation between the Public Administration pay gap and country characteristics linked to the government monopolistic power in the provision of public services, the labor market institutions, and the business cycle. This is a table analogous to Table 9, but the wage gap is that of the Public Administration (industry O) vs. the rest of the economy, whereas in Table 9, it is that of the NACE proxy to the government sector (industries $\mathrm{O}, \mathrm{P}$, and Q) vs. the rest of the economy. The presence of the private sector is negligible in industry $\mathrm{O}$, whereas it can have a large presence in industries $\mathrm{P}$ and $\mathrm{Q}$, depending on the country. Robust standard errors are in parenthesis

Significance levels: *10\%; ${ }^{* *} 5 \% ;{ }^{* * *} 1 \%$ 

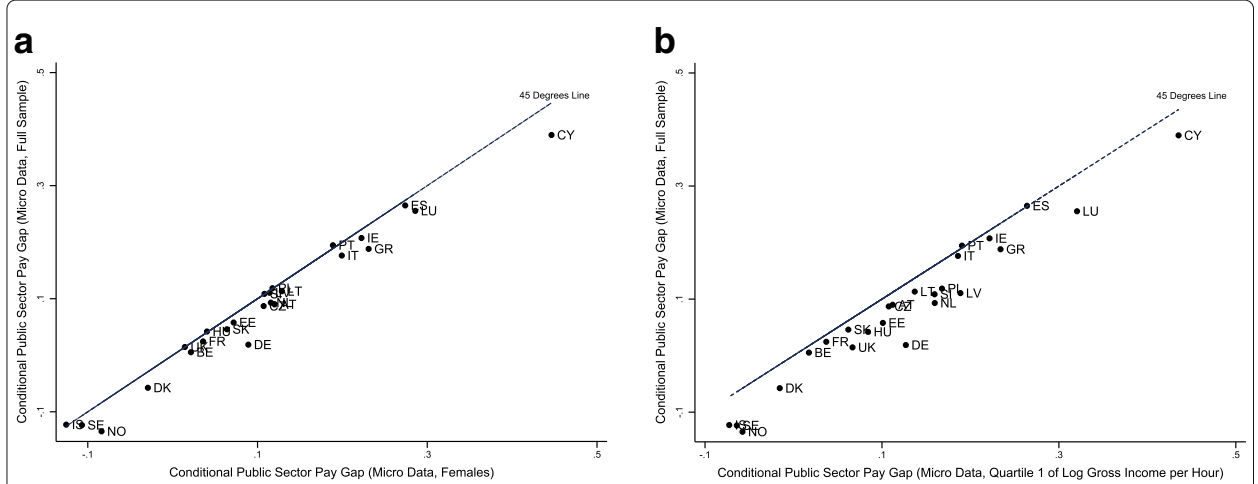

Fig. 5 Public-private pay differentials of women and low-income workers and comparison with overall pay gaps. Notes: Panel a compares the public sector pay gap conditional on observed worker characteristics (EU-SILC, see Eq. (1)) of the full sample and the sample of female workers. Panel $\mathbf{b}$ compares the pay gap of the full sample with that of workers at the first quartile of the income distribution. The gap of female workers is computed by estimating Eq. (1) for the sample of female workers. The gap of low-income workers is computed via a quantile regression with the same covariates as in Eq. (1). In almost all the countries, the gaps of women and low-income workers are larger than that of the full sample. Nevertheless, the cross-country differences remain

\section{Acknowledgements}

We thank Olympia Bover, Ewa Galeka-Burdziak, Tarek M. Harchaoui, at least one anonymous referee, and seminar participants at Banco de España (9 July 2015), INFER Workshop on Applied Macroeconomics and Labour Economics (Seville, 5-6 November 2015), Encuentro de Economía Pública (Ourense, 4-5 February 2016), and the Annual Meeting of the European Public Choice Society (Freiburg, 30 March-2 April 2016) for discussions and comments. The views expressed in this paper are those of the authors and do not necessarily coincide with the views of the Bank of Portugal, the Bank of Italy, the Bank of Greece, the Bank of Spain, or the Eurosystem.

Responsible editor: Denis Fougère

\section{Competing interests}

The IZA Journal of Labor Policy is committed to the IZA Guiding Principles of Research Integrity. The authors declares that they have observed these principles.

\section{Publisher's Note}

Springer Nature remains neutral with regard to jurisdictional claims in published maps and institutional affiliations.

\section{Author details}

${ }^{1}$ Bank of Portugal, Av. Almirante Reis, 71-6th floor, 1150-012 Lisbon, Portugal. ${ }^{2}$ Bank of Italy, Via Nazionale 91, 00184 Roma, Italy. ${ }^{3}$ Bank of Greece, 21 E. Venizelos Avenue, 10250 Athens, Greece. ${ }^{4}$ Bank of Spain, Calle Alcalá 48, 28014 Madrid, Spain.

Received: 21 April 2017 Accepted: 4 July 2017

Published online: 27 July 2017

\section{References}

Alesina A, Baquir R, Easterly W (2000) Redistributive public employment. J Urban Econ 48(2):219-241

Becker G, Stigler J (1974) Law enforcement, malfeasance, and the compensation of enforcers. J Legal Stud 3:1-18 Blinder AS (1973) Wage discrimination: reduced form and structural estimates. Journal of Human Resources 8(4):436-455 Caponi V (2014) Public employment policies and regional unemployment differences. IZA Discussion Paper No 8511 Cavalcanti T, Rodrigues dos Santos M (2015) (Mis)allocation effects of an overpaid public sector, mimeo. University of Cambridge and Insper

Christofides L, Michael M (2013) Exploring the public-private sector wage gap in European countries. IZA J Eur Labor Stud 2(15). https://izajoels.springeropen.com/articles/10.1186/2193-9012-2-15

Depalo D, Giordano R, Papapetrou E (2015) Public-private wage differentials in euro-area countries: evidence from quantile decomposition analysis. Empir Econ 49(3):985-1015

Dickson M, Postel-Vinay F, Turon H (2014) The lifetime earnings premium in the public sector: the view from Europe. Labour Econ 31:141-161

Elder TE, Goddeeris JH, Haider SJ (2010) Unexplained gaps and oaxaca-blinder decompositions. Labour Econ 17:284-290

European Commission (2014) Government wages and labour market outcomes. European Economy Occasional Papers 190

Fernández-de-Córdoba G, Pérez JJ, Torres JL (2012) Public and private sector wages interactions in a general equilibrium model. Public Choice 150:309-326

Forni L, Novta N (2016) Public employment and compensation reform: the role of social dialogue and structural measures. Int Tax Public Financ 23(5):960-979 
Giordano R, Depalo D, Pereira MC, Eugène B, Papapetrou E, Pérez JJ, Reiss L, Roter M (2015) The public sector pay gap in a selection of euro area countries in the pre-crisis period. Hacienda Pública Española/Rev Public Econ 214:11-34

Holm-Hadulla F, Kamath K, Lamo A, Pérez JJ, Schuknecht L (2010) Pubic wages in the euro area. towards securing stability and competitiveness. ECB Occasional Paper Series No. 112

Holmlund B (1993) Wage setting in private and public sectors in a model with endogenous government behavior. Eur J Polit Econ 9(2):149-162

Holmlund B (1997) Macroeconomic implications of cash limits in the public sector. Economica 64(253):49-62

Hospido L, Moral-Benito E (2014) The public sector wage premium in Spain: evidence from longitudinal administrative data, Banco de España Working Papers 1422

Kaufmann D, Kraay A, Mastruzzi M (2010) The worldwide governance indicators methodology and analytical issues, the World Bank. Policy Research Working Paper

Kollintzas T, Papageorgiou D, Vassilatos V (2015) A model of market and political power interactions for Southern Europe, cEPR Discussion Paper 10359

Lamo A, Pérez JJ, Sánchez-Fuertes J (2013) Institutional determinants of public-private sector wages' linkages. Appl Econ Lett 20(12):1165-1169

Lausev J (2014) What has 20 years of public-private pay gap literature told us? Eastern European transitioning vs. developed economies. J Econ Surv 8(3):516-550

Lindquist MJ, Vilhelmsson R (2006) Is the Swedish central government and wage leader? Appl Econ 38(14):1617-1625

Llorens JJ (2008) Uncovering the determinants of competitive state government wages. Review of Public Personnel Administration 28(4):308-326

Marconi N, Arvate PR, Moura-Neto JS, Palombo PE (2009) Vertical transfers and the appropriation of resources by the bureaucracy: the case of Brazilian state governments. Public Choice 141:65-85

Matschke X (2003) Are there election cycles in wage agreements? An analysis of German public employees. Public Choice 114:103-135

Neumark D (1988) Employers' discriminatory behavior and the estimation of wage discrimination. J Hum Resour 23(3):279-295

Oaxaca R (1973) Male-female wage differentials in urban labor markets. Int Econ Rev 14(3):693-709

Peichl A, Pestel N, Siegloch S (2013) The politicians' wage gap: insights from German members of parliament. Public Choice 43(3):653-676

Pérez JJ, Aouriri M, Campos MM, Celov D, Depalo D, Papapetrou E, Pesliakaité J, Ramos R, Rodríguez-Vives M (2016) The fiscal and macroeconomic effects of government wages and employment reform, European Central Bank Occasional Paper Series No 176

Teorell J, Dahlberg S, Holmberg S, Rothstein B, Hartmann F, Svensson R (2015) The quality of government standard dataset, version jan15, University of Gothenburg: The Quality of Government Institute, Sweden. http://qog.pol.gu.se/ data/datadownloads/qogstandarddata

Visser J (2013) Data base on institutional characteristics of trade unions, wage setting, state intervention, and social pacts, 1960-2011 (ictwss), Amsterdam Institute for Advanced Labour Studies AIAS, University of Amsterdam

\section{Submit your manuscript to a SpringerOpen ${ }^{\circ}$ journal and benefit from:}

- Convenient online submission

- Rigorous peer review

- Open access: articles freely available online

- High visibility within the field

- Retaining the copyright to your article

Submit your next manuscript at $\boldsymbol{\triangleright}$ springeropen.com 